\title{
Accounting research in China: commemorating the 40th anniversary of reform and opening up
}

\author{
Huacheng Wang ${ }^{1}$, Kangtao Ye ${ }^{1}$ and Kai Zhong ${ }^{2^{*}}$
}

\footnotetext{
* Correspondence: ytkaiz@126.com ${ }^{2}$ University of International Business and Economics, Beijing, China Full list of author information is available at the end of the article
}

\begin{abstract}
This study reviews the influential accounting literature on China topics published both in international and Chinese journals in the recent four decades to celebrate the 40th anniversary of the reform and opening up in China. We first review the literature published in the first two decades, where normative research is dominant and financial accounting and managerial accounting are the main topics. Then, looking more in-depth at the most recent literature, we separately discuss the articles published from 1998 to 2007 and from 2008 to 2018, in which many topics are covered including financial accounting, managerial accounting, financial management and corporate governance, auditing and tax. Finally, conclusions and future suggestions are raised based on the issues explored over the past four decades.
\end{abstract}

Keywords: Literature review, Reform and opening up, Financial accounting, Managerial accounting, Auditing

\section{Introduction}

China has made remarkable achievements in economic development since the reform and opening up in 1978. Accounting, a systematic process of capturing information to reflect economic activities, has also changed considerably with the rapid growth of China's economy. Thus, more attention needs to be paid to accounting research, through which we can examine whether the system of accounting is efficient. In this paper, we review accounting research in China since the reform and opening up policy was launched in 1978 so as to provide a framework for Chinese accounting research and provide suggestions for future research.

We divide this review into two main sections: accounting research in the early stage (1978-1997), when normative research is dominant, and accounting research in the current stage (1998-2017), when most articles use empirical methodologies. In each section, we first briefly introduce the evolution of institutions most related to accounting in China. Then we review the accounting literature related to China within different fields: financial accounting, managerial accounting, financial management and corporate governance, auditing, ${ }^{1}$ and tax. The structure of this survey is shown in Fig. 1.

The articles reviewed come from both leading international and Chinese journals published during 1978-2018. ${ }^{2}$ The articles published in leading international journals

(c) The Author(s). 2018 Open Access This article is distributed under the terms of the Creative Commons Attribution 4.0 International License (http://creativecommons.org/licenses/by/4.0/), which permits unrestricted use, distribution, and reproduction in any medium, provided you give appropriate credit to the original author(s) and the source, provide a link to the Creative Commons license, and indicate if changes were made. 


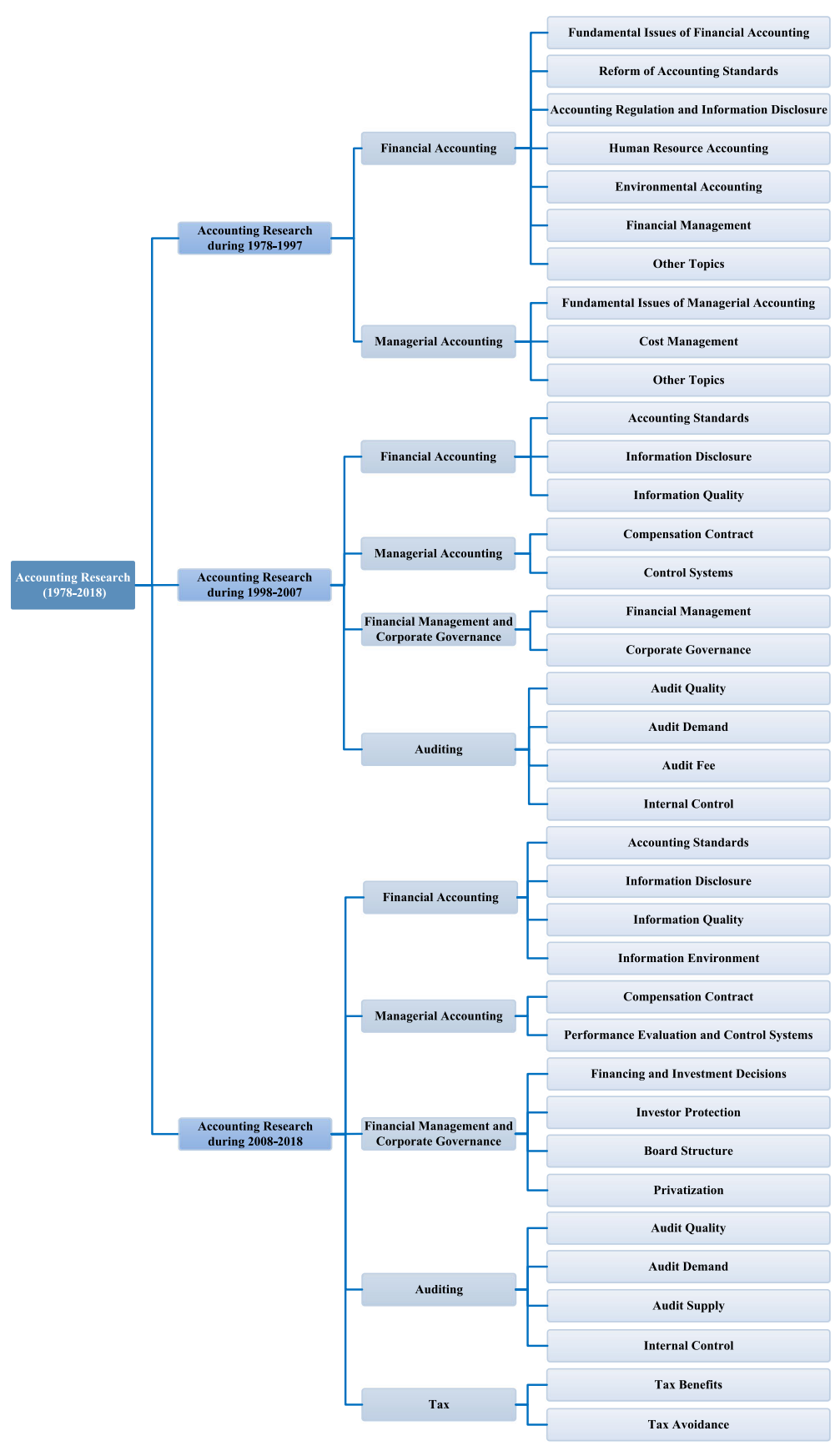

Fig. 1 The structure of this review

are restricted to China related issues. The leading international journals include 10 journals, namely, top-6 accounting journals, including: The Accounting Review, Journal of Accounting and Economics, Journal of Accounting Research, Contemporary Accounting Research, Review of Accounting Studies, and Accounting, Organization, and Society; and top-4 finance journals, including: Journal of Finance, Journal of Financial Economics, Review of Financial Studies, and Journal of Financial and Quantitative Analysis. 
To broaden the review scope, for the Chinese journals, the reviewed articles related to accounting issues are from 4 top-ranked accounting journals, Accounting Research, Auditing Research, China Accounting Review, and China Accounting and Finance Review; 2 top-ranked economics journals, Economic Research Journal, and Journal of Financial Research; and 2 top-ranked management journals, Management World, and Nankai Business Review. Since there are thousands of articles published in the above leading Chinese journals, the articles included in this survey are influential ones which are highly cited in the CSSCI. ${ }^{3}$ The first section, accounting research in the early stage, covers the top-100 highly cited articles ${ }^{4}$ published in Accounting Research because the research on accounting, management, and economics was separated during the 19781997. For the second section, positive accounting research in the current stage, we divided it into two 10-year periods. Each part contains 120 influential articles from the above leading accounting, economics, and management Chinese journals (30 articles in Accounting Research, 20 articles in Auditing Research, 15 articles in Economic Research Journal and Management World, 10 articles in China Accounting Review, China Accounting and Finance Review, Journal of Financial Research, and Nankai Business Review). ${ }^{5}$ Table 1 presents the number of articles from each journal in this survey. ${ }^{6}$

In Section 2, we first briefly introduce the evolution of institutions related to accounting during the 1978-1997 period. Then we discuss the literature in the financial accounting and managerial accounting fields respectively. Section 3 shows the institutional evolution related to accounting during 1998-2018. Then we review the literature published from 1998 to 2007 and 2008-2018 separately by different fields.

Table 1 Number of articles from each journal

\begin{tabular}{ll}
\hline Journal & No. \\
\hline International Journals & 18 \\
The Accounting Review & 4 \\
Journal of Accounting Research & 11 \\
Journal of Accounting and Economics & 11 \\
Contemporary Accounting Research & 6 \\
Review of Accounting Studies & 17 \\
Accounting, Organization, and Society & 4 \\
Journal of Finance & 10 \\
Journal of Financial Economics & 10 \\
Review of Financial Studies & 11 \\
Journal of Financial and Quantitative Analysis & \\
Chinese Journals & 160 \\
Accounting Research & 40 \\
Auditing Research & 20 \\
China Accounting Review & 20 \\
China Accounting and Finance Review & 20 \\
Economic Research Journal & 30 \\
Management World & 30 \\
Journal of Financial Research & 20 \\
Nankai Business Review &
\end{tabular}

Notes. This table describes the number of articles from each journal included in this review 


\section{Accounting research in the early stage (1978-1997)}

In this section, we first introduce the most influential institutions or regulations implemented starting from 1978, the beginning of the reform and opening up policy, to 1997. As most accounting research topics result from the study of institutions or regulations, the introduction of the evolution of institutions may help bring about a better understanding of accounting research during this period. Then literature published in leading international and Chinese journals from 1978 to 1997 is discussed.

\section{Institutional evolution during 1978-1997}

Here we will briefly introduce the institutions developed from 1978 to 1997, through which we may better understand the topics of accounting research during this period. The following briefly describes some influential institutions established during this period in chronological order.

- Reform and Opening Up Policy (1978)

- Emergence of Chinese stock markets (1990-1991): The Shanghai Stock Exchange and the Shenzhen Stock Exchange were established in December 1990 and July 1991 respectively.

- Issuing of B-shares (1992): The B-share market of China was first established in 1992, which only allowed foreign investors to purchase stocks in Chinese listed firms.

- The first Chinese Accounting Standards (1992): The first Chinese Accounting Standards were released in 1992 and were required to be implemented in 1993.

- The foundation of the China Securities Regulatory Commission (CSRC): CSRC is an institution of the State Council with ministry-level rank. It is the main regulator of the securities industry in China and was set up in 1992.

- The first Corporate Law in China (1993): The first Corporate Law in China was promulgated by the Standing Committee of the National People's Congress in 1993.

There is a transition from a planned economy to a market-oriented economy during 1978-1997, and the accounting system in China changed considerably with this economic transition. Thus, most accounting literature in this period discussed how to construct the accounting system in China at that time, especially for financial accounting and managerial accounting.

\section{Accounting research during 1978-1997}

From 1978 to 1997, accounting literature in China is mostly normative research, which mainly focuses on financial accounting and managerial accounting.

\section{Financial accounting}

Financial accounting literature in China during 1978-1997 mainly investigates the following topics: the fundamental issues of financial accounting, the reform of accounting standards, accounting regulation and information disclosure, human resource accounting, environmental accounting, financial management, and other topics. We review each of the above topics as follows. 
Fundamental issues of financial accounting First of all, the question of what is accounting is the most important issue during the early stage period. Some literature summarize the definition of accounting as the following four concepts: management tool, management activity, art, and information system based on definitions in both domestic and foreign materials including textbooks, encyclopedias, literature, and reports of accounting associations. Zhou (1988) briefly introduces the Chinese accounting system, relating the nature of the Chinese accounting system to the specific socio-economic context in China. Subsequently, Wu (1996) argues that accounting is used to reflect firm stewardship and defines accounting as an economic control system which aims at affirming and measuring accountability with monetary measurement. However, Zhao (1995b) summarizes the objective of accounting as the integration of accountability and decision availability. Huang (1997b) notes that the debate about accounting objectives is meaningless if the function of accounting is neglected. He considers recording and supervision to be the functions of accounting and that discussions of the objective of accounting should be restricted to the functions of accounting. Moreover, one article explores the essence and content of accounting culture. He defines accounting culture as accounting ideology, its corresponding system, and implementation, whereas the content of accounting includes accounting values, accounting ethics, and accounting law.

Several studies focus on accounting identification, accounting measurement, and accounting policy. The basis of accounting identification is accrual accounting, butliterature raises the concept of cash flow based accounting, adjusted from cash based accounting, that could provide more useful information for decision making and solve the limitations of accrual based accounting. For accounting measurement, Lin (1997) investigates the relationship between uncertainty and accounting which argues that accounting has a time-lag and that uncertainty comes from monetary measurement. Xie (1997) presents two non-monetary asset measure models on the labor theory of value and marginal utility theory of value which are different from the capital preservation concept of accounting. Meanwhile, with the development of financial derivatives, Huang (1997a) believes that historical cost accounting will be replaced by fair value accounting in the twenty-first century and briefly introduces the concept of fair value accounting in accounting standards issued by the Financial Accounting Standards Board (FASB). With respect to accounting policy, Huang and Yang (1995) explore questions such as what is accounting policy and why there is accounting policy. They regard accounting policy as the principle, procedure and method by which a certain accounting unit is used to make financial statements, including macro-level accounting policy such as accounting standards, and firm-level accounting policy issued by the firms themselves according to their particular situations. Consistent with Huang and Yang (1995), $\mathrm{Li}$ and Zhu (1996) argue that accounting environment and firm operation should be taken into consideration for the choice of accounting policy. As well, Huang and Yang (1996) investigate accounting policy in details, that is the separation between financial accounting and tax accounting in accounting policy. Financial accounting and tax accounting are separated due to different objectives, legislative authority and calculation principles. Compared with accounting development internationally, Tang and Lu (1997) put forward the challenge for financial accounting in China, including accounting identification, accounting measurement, financial reporting, accounting theory, the release 
and diffusion of accounting information, and the combination of financial accounting and managerial accounting.

Finally, accounting theory is another important topic in financial accounting research during the 1978-1997 period. Research in accounting theory is first put forward in Yang and Yan (1980), where they argue that more attention has been paid to accounting practices while accounting theories have largely been ignored. Xie (1995) further suggests that the accounting environment is the logical starting point for an accounting theory framework. Some important questions are also raised in accounting research to provide guidance for accounting research and practice.

Reform of accounting standards Literature on the reform of accounting standards not only focuses on the fundamental nature and conceptual framework of accounting standards, but also introduces some specific accounting standards, especially goodwill and financial derivatives.

The core of accounting standards is an objective constraint mechanism, which comes from political activities and has economic consequences. Meanwhile, some studies regard accounting standards as a property rights arrangement based on Coarse Theorem. Consistent with this view, some literature also suggests that accounting standards are a contractual arrangement. Ge (1997) further presents how to construct a financial accounting conceptual framework with the reform of basic accounting standards. Moreover, studies suggest that financial reporting should be improved due to the demand for information and economic development.

For definite accounting standards, studies mainly concentrate on goodwill and financial derivatives. Luo (1997) explores the essence of goodwill and its accounting processes. Their views are very similar to the definition of goodwill in current accounting standards. As well, Luo (1997) raise the concept of internally generated goodwill. For the studies of financial derivatives, some of them introduce accounting standards for financial instruments (Yan and $\mathrm{Xu} \mathrm{1995).} \mathrm{Others} \mathrm{focus} \mathrm{on} \mathrm{the} \mathrm{ef-}$ fect of financial instruments on accounting, including identification, component, measurement and disclosure, where they argue for fair value accounting (Ge and Chen 1995; Lu 1996; Wu 1997).

Accounting regulation and information disclosure When discussing accounting regulation, formal regulation comes from accounting rules, laws, or regulations and informal ones from ethics. Xia and Liu (1995) investigate the relationship between government and accounting regulation, in which they describe reasons, incentives and range of formal accounting regulation. Subsequently, the role of accounting regulations in the issue of insider control during the transition period has also been explained. One article compares the differences in accounting between China and Western countries, suggesting that accounting regulation is derived from culture. Chen (1995b) discusses accounting supervision and proposes that accounting ethics are a complement to formal accounting regulations. The concept and function of accounting ethics are raised in discussions of informal accounting regulations ( $Y u$ 1996). As well, it is suggested that referring to the American experience is a good idea in improving the accounting ethics system. 
The objective of enhancing accounting regulations is to increase information disclosure quality. Information disclosure opacity may result from weak accounting regulation, especially for state-owned firms (Chen and Lu 1996). Under the efficient market assumption, Sun (1997) suggests that the increased quality of information disclosure is essential for the proper functioning of stock markets and accounting regulation should be rooted in the Chinese context. In addition, Wang (1997b) introduces earnings forecasts with experiences from different countries, which contributes to the disclosure of earnings forecasts in China.

Human resource accounting Human resources are a key asset for firms. Several studies explore their identification, measurement, and disclosure although accounting standards do not allow human resources to be recognized as an asset in financial statements. Zhang (1987) holds that human resources can be regarded as an asset and that doing so accords with the requirements of capitalization. Consistent with Zhang (1987), Zhao (1995a), Zhang (1995) and Du (1997) also consider human resources as an intangible asset that could be capitalized. Moreover, they suggest the disclosure of human resources could provide more useful information for users. For the measurement of human resource value, Du (1997) and Liu (1997) provide some methods to measure the value of human resources. In addition, following the view of capital maintenance, $\mathrm{Hu}$ (1995) raises the concept of human capital maintenance. Some literature generally provides a labor rights oriented framework for human resource accounting.

Environmental accounting With the concept of green accounting rising in Western countries, Ge and Li (1992) as well as Feng and Shen (1995) offer an introduction to green accounting theory and practice in Western countries. Meanwhile, Meng (1997a) emphasizes that environmental accounting is an emerging area and further investigation is necessary. Furthermore, Meng (1997b) investigates the core concepts of environmental accounting. He argues that environmental accounting is a combination of environics, environmental economics, development economics, and accounting, whereby its function is similar to financial accounting but its object is activities related to the environment. As well, in a more general view, Wu (1994) focuses on the foundation and content of social responsibility accounting, which not only includes environment protection, but also is composed of the firm's responsibility to employees, communities, customers and so on.

Financial management Literature on financial management can be divided into two areas. One focuses on the fundamental issues of financial management, and the other on specific topics in financial management.

First, Guo (1996) reviews the fundamentals, function, and content of financial management. Zhang (1997) examines the objectives of financial management, which he associates with economic institutions, and also looks at the relationship of capital maintenance, capital gain, profit, and economic benefit to financial management. Moreover, based on the theory of property rights, some studies focus on the entity of financial management (Liu, 1995), property rights management (Tang, 1994), ownership 
oriented financial management (Xie 1997), and layer-management of financial management with China's institutions (Wang, 1997a).

Furthermore, several studies investigate specific topics in financial management, including financial distress (Zhou et al. 1996), working capital management (Mao 1995), financial risk (Xiang 1994), debt overhang (Yan and Geng 1996), off-balance-sheet financing (Chen 1995a), and valuation methods (Tian and Li 1997).

Other topics Besides the above areas, there is literature on accounting information systems and accounting education. As well, positive accounting research is arising and several studies provide empirical evidence on financial accounting issues.

Li et al (1996) argue that accounting information systems should not only be systems of information management, but also work as systems for decision-supporting. Xue (1997) introduces the characteristics of a computerized accounting system while internal control is also an important topic. In addition, literature investigates how information technology will affect financial reporting through mass communication.

Literature on accounting education mainly focuses on the following issues: the objectives of accounting teaching ( $\mathrm{Fu} \mathrm{1994),} \mathrm{course} \mathrm{classification,} \mathrm{the} \mathrm{reform} \mathrm{of} \mathrm{master} \mathrm{edu-}$ cation of accounting (Chen, 1996), and the comparison of accounting education between China and Western countries (Zhou et al. 1997).

Besides the above normative accounting research, positive accounting research emerged in the 1990s. Hao (1997) and Chen (1997b) introduce the case study method and empirical analysis method in accounting research respectively, which provide guidance for positive accounting research. As well, Zhang and Xu (1997) suggest that the launch of positive accounting research could be supportive for the improvement of stock market regulation. Using empirical analysis, the following issues are examined: the efficiency of China's stock markets (Chen et al. 1997), the relation between earnings and stock return, accounting information disclosure and the semi-efficiency of China's stock markets, and the difference of after tax earnings between domestic and overseas audit reports (Li 1997).

\section{Managerial accounting}

Managerial accounting literature in China during the 1978-1997 period mainly investigates the following topics: the fundamental issues of managerial accounting and cost management. We review each of these topics.

Fundamental issues of managerial accounting As with financial accounting, the question of what is managerial accounting and what are its applications are the focus of research. Li (1988) places managerial accounting in Western countries into two areas: traditional managerial accounting which is centered on cost, and innovative managerial accounting which is in favor of the expectation with mathematical model. Meanwhile, it is shown that how the adoption of Western management accounting methods by state-owned Chinese firms has played an integral and demonstrable role in China's economic development. Literature suggests that managerial accounting should pay more attention to performance evaluation as well as cost management since traditional managerial accounting is inadequate for management activities. Song (1995) 
posits that managerial accounting is also a system for decision-making rather than a method to manage activities, and he calls for research on the theoretical framework of managerial accounting to include objectives, fundamentals, theory, basic principles, basic elements, and so on. Meng (1997c) raises three ways to increase normalization for managerial accounting: theory summarization from practices, formulating guidance for managerial accounting, and compiling textbooks of managerial accounting. Meanwhile, Wang and Yang (1997) suggests that managerial accounting should be considered with corporate strategy including risk management, cost management, operating investment, and human resource management. Moreover, Wang and He (1997) propose that managerial accounting research should not only be normative, but also introduce field studies.

With regards to the application of managerial accounting, He (1997) find that the attention from senior leadership, the internal environment, and the ability of accountants may impede the application of managerial accounting, and managerial accounting systems should adapt to the institutions of law, culture and economic conditions based on their surveys. Consistent with the above literature, it is also found that the application of managerial accounting in China is not sufficient, and they suggest that field studies and case studies could be helpful in facilitating the application of managerial accounting. Feng (1997) proposes to develop the framework of managerial accounting in China in the following four areas: economic profit, responsibility, methodology, and specialization. Furthermore, Qiao (1997) investigates why there has been weak application of managerial accounting in state-owned firms and he suggests that internal and external motivation should be enhanced. Evidence is provided that Chinese enterprises who participate in foreign partnered joint ventures make more changes to their management control systems including the accounting techniques employed by the joint venture.

Cost management Besides studies on the fundamental issues of managerial accounting, some of the literature concentrates on a specific activity of managerial accounting: cost management. An introduction to activity-based cost (ABC) management is provided and Chen (1997a) introduces the Japanese experience in cost management. Literature argues that $\mathrm{ABC}$ management could provide more accurate information about costs while Sun (1995) and Xiao and Pan (1996) further explain the method for cost calculation based on ABC management. Moreover, Lu (1995) emphasizes that cost management should pay more attention to corporate strategy which could assist in making more efficient investment decisions. Unlike the above literature focused on corporate cost management, the education cost calculation in colleges and universities is also discussed.

Other topics International accounting journals have also published several articles related to transfer pricing and internal audit in China. Chan and Chow (1997) investigate the impact of tax audits in China on international transfer pricing and find that tax authorities focus on profit rather than prices and often use the comparable profits method to adjust income. Kachelmeier and Shehata (1997) provide evidence that 
audit-based monitoring is less effective and less in demand in China than in Canada due to the difference in cultural values.

\section{Accounting research in the current stage (1998-2018)}

In this section, we review the articles published from 1998 to 2018. In this period, positive accounting research is dominant. First, we provide a brief introduction of the evolution of institutions relevant to the discipline of accounting in China. Then, we review the literature for each decade separately for a more in-depth understanding of research in this period.

The evolution of institutions during 1998-2018

Here we briefly introduce the institutions established during the 1998-2018 period, which help us better understand the trends in accounting research during this time.

- The Security Law in China (1998): The first Security Law in China was announced by the Standing Committee of the National People's Congress in 1998, supporting the stable development Chinese stock markets.

- Introduction of Qualified Foreign Institutional Investors (2002): Qualified Foreign Institutional Investors were allowed to invest in A-share markets since 2002 by the CSRC.

- Stock Split Reform (2005): This reform was implemented to convert non-tradable shares into tradable ones by the CSRC starting from 2005. Before the reform, non-tradable shares could not be freely traded, and they could be exchanged only at a negotiated price under special circumstances, often requiring government approval. Trading restrictions of non-tradable shares were gradually removed after a firm implemented the reform and the non-tradable shares were locked for 12 months after the completion of the reform.

- The new China Accounting Standards (2007): The new China Accounting Standards were issued by China's Ministry of Finance in 2006 and came into effect in 2007. They are substantially in line with International Financial Reporting Standards (IFRS). The most important issue in the new China Accounting Standards is the adoption of fair value accounting.

- C-SOX (2008, 2010): The Internal Control Standards were implemented to increase internal control quality in 2008 by China's Ministry of Finance, the CSRC, the Audit Commission, the China Banking Regulatory Commission, and the China Insurance Regulatory Commission, which requires the self-evaluation of internal control and its disclosure. After that, the Internal Control Guidelines was released in 2010, which states the adoption time and provides guidance for the disclosure and auditing of internal control.

- Stock Connect Scheme (2014, 2016): The CSRC and the Securities and Futures Commission (SFC) of Hong Kong in 2014 jointly announced the "Shanghai-Hong Kong Stock Connect" scheme, which allows investors from both the mainland and Hong Kong to trade securities in each other's markets through the trading and clearing facilities of their home exchange. As well, the "Shenzhen-Hong Kong Stock Connect" scheme was implemented with a similar framework in 2016. 
These are some of the important regulations and institutions established during the 1998-2018 period to enhance the stable development of capital markets. At this time, the accounting literature explores whether changes in regulations can increase information quality and market efficiency to provide evidence for the development of these institutions. For example, some studies investigate whether the value relevance of accounting information increased with the issuing of new accounting standards in 2006 and others examine the topic of internal control in the context of the issuance of C-SOX.

\section{Accounting research in 1998-2007}

We divide accounting research into the following four areas: financial accounting, managerial accounting, financial management and corporate governance, and auditing. These are the major topics in the accounting literature during the 1998-2007 period.

\section{Financial accounting}

Accounting standards are the most important issue in financial accounting and studies in this period investigate whether the reform of accounting standards can provide more useful information with empirical evidence. Aside from accounting standards, and different from normative accounting research, most financial accounting literature from 1998 to 2007 focuses on the following two aspects: information disclosure and its association with capital markets; and, the determinants and consequences of information quality. ${ }^{7}$ The information environment is also another important financial accounting issue, but due to data availability, there is less literature on this topic with the exception of the evidence presented that analysts can improve stock price efficiency.

Accounting standards The accounting regulation system in China (2007) is introduced, where they argue that political ideology influences how the accounting regulation system is set up. The accounting choice of impairment is investigated, in which he provides evidence that companies use asset impairment for earnings manipulation. With the reform of Chinese accounting standards in 2006, Zhang et al. (2007) further find that managers are more cautious in their use of asset impairment that cannot be reversed in the future, suggesting that the reform may restrict a "big bath" with asset impairment. Furthermore, Deng (2005) provides evidence that fair value accounting could increase the informativeness of accounting earnings with the adoption of IAS39 in the B-share market.

Information disclosure Due to data availability and stock market development, studies on information disclosure and its association with capital markets emerged at the end of the 1990s using empirical research methods. We divide this literature into the following two parts: accounting information disclosure and capital markets; and, the explanation of stock market returns.

The studies on accounting information disclosure and capital markets mostly investigate whether accounting information, especially earnings, is associated with stock market return under the assumption of efficient markets. Using the earnings response coefficient (ERC) model, the informativeness of earnings with stocks listed on the 
Shanghai Stock Exchange is verified, especially after the implementation of accounting standards in 1993. Consistent with the above view, Chen et al. (1999) find similar results with the sample of stocks listed on both the Shanghai and Shenzhen Stock Exchanges. Based on the residual income model, the value relevance of accounting information is supported in most literature. Evidence is shown that higher information disclosure quality can decrease the cost of capital as well. Meanwhile, evidence is provided that information disclosure quality increases with good corporate governance. Another part of the literature investigates the impact of information disclosure on debt markets verifies the contracting role of information disclosure. However, they find that the contracting role of accounting information is mainly relevant in non-state-owned companies due to government intervention in bank loans. Chen (1998) discusses the information characteristics of the family-based informal organization through transaction cost theory.

Another issue is which factors affect stock returns aside from accounting information and the literature on this issue is diffuse. Evidence is provided that size and book-to-market ratio have significant effects on stock returns. Li and Wu (2000) focus on initial public offering (IPO) returns, and they provide evidence that there is IPO underpricing in the Chinese market. Yang and Yao (2004) find that the risk of informative trading is lower than non-informative trading, implying that private information is more important for stocks with low liquidity. Literature further investigates the asymmetric stock market response of "good" and "bad" news with the EGARCH model, showing that the positive feedback effect drives the volatility of Chinese stock markets. For cross-listings in $\mathrm{B}$-shares or $\mathrm{H}$-shares, evidence is shown that $\mathrm{B}$-share market return may be explained by A-share market irreversibly and cross-listing only has a cash dispersion effect rather than a risk sharing effect. Zhao and Wang (1999) and Li and Niu (2007) provide evidence about the fixation effect on stock market anomalies.

In addition, some studies investigate the effects of non-financial information disclosure, especially corporate social responsibility, which was disclosed voluntarily at that time. It is found that firm size and profitability are the determinants for information disclosure on environmental indicators and aside from firm size and profitability, the location of listing and the regulation environment are determinants of corporate social responsibility disclosure. Furthermore, Chen and Ma (2005) show that the value relevance of corporate social responsibility disclosure was weak at that time.

Information quality Earnings quality is widely defined as follows: "Higher quality earnings provide more information about the features of a firm's financial performance that are relevant to a specific decision made by a specific decision-maker." Thus, we review the literature on information quality including earnings management, accounting irregularities, and other measurements for information opacity.

Literature on earnings management mainly focuses on which factors induce incentives to earnings manipulation and how to impede earnings management. The incentives of earnings management result from financing demand, such as IPOs and SEOs (seasoned equity offerings) (Chen et al. 2000a, 2000b), listing requirements (Lu 1999), and compensation contracts. However, earnings management may be restricted by strong corporate governance including the ownership of controlling shareholders, independent directors, and the controlling power of blockholders. Evidence is provided that 
earnings management can induce the turnover of independent directors. As well, it is founds that earnings management is associated with taxes on boot, implying that firms manipulate non-tax earnings to avoid the tax costs induced by earnings management.

Regarding the measurement of earnings management, most articles use the Jones model or DD model to calculate the proxy for earnings management. However, evidence is found that extraordinary items, including government subsidies and income from non-operating activities, are usually used when manipulating earnings, suggesting the need to consider this variable in earnings management studies. Xia (2003) summarizes the validity of earnings management measurement in China including the above proxies. It is shown that strong corporate governance could mitigate accounting irregularities, where corporate governance is measured by board size, independent directors, audit committee, and ownership structure. Moreover, consistent with the above evidence, Liu and $\mathrm{Du}$ (2003) also show that accounting fraud is mitigated with strong corporate governance.

Furthermore, other variables are used to proxy information, including earnings conservatism, earnings aggressiveness, earnings smoothing, earnings timeliness, earnings response coefficients, and information disclosure assessment results. Conservatism is one of the accounting principles and $\mathrm{Li}$ and $\mathrm{Lu}$ (2003) provide evidence that accounting conservatism exists in Chinese listed firms where stock returns react more strongly to bad news than good. However, evidence is shown that the conservatism in Chinese listed firms results from "big bath" behavior and conservatism disappears when controlling for loss. Further, accounting conservatism is one of the determinants of debt contracts. For other earnings attributes, earnings aggressiveness and earnings smoothing can increase the cost of equity. Similar to the above literature, information transparency, measured by earnings aggressiveness and earnings smoothing, could increase the likelihood of CEO turnover with decreased profitability.Earnings timeliness, another earnings attributes, is associated with institutional ownership. It is demonstrated that strong corporate governance can improve earnings response coefficients, and this is verified by Wang and Tong (2006) with ownership structure. Finally, with the information disclosure assessment results provided by the Shenzhen Stock Exchange, Gao and Song (2007) find similar results consistent with prior evidence.

\section{Managerial accounting}

The managerial accounting literature mostly investigates compensation contracts and control systems. There has been a small amount of focus on performance evaluation, showing the description of three patterns for performance evaluation: a finance pattern, a value pattern and a balance pattern, the last of which they suggest should be adopted by Chinese firms. The following will review the literature on compensation contracts and control systems.

Compensation contract Most compensation contract literature examine the determinants and structure of compensation contracts and whether they contribute to good performance. There are also studies exploring the compensation gap.

In general, evidence is presented that CEO compensation is a function of firm size, profitability, intangible assets, and state ownership. However, with the restriction on 
compensation in state-owned companies, Xin et al. (2007) find that perks work as a substitution for compensation as well as over-investment. Furthermore, the restriction on compensation in state-owned companies weakens the association between profitability and compensation. Regarding the compensation in commercial banks, Chen (2005) suggests that compensation should not only be associated with profitability in commercial banks, but also be related with the quality of assets. Meanwhile, several studies investigate stock options and provide evidence that stock options are affected by corporate governance such as board structure, ownership, etc. Whether compensation brings about good performance is also discussed and compensation is positively associated with performance but Li (2000) finds that it has an insignificant effect.

The compensation gap is another issue in managerial accounting covered in the literature in the 1998-2007 period. Evidence is found that growth opportunity and internal competition are the determinants of compensation gaps. Compensation gaps can result in good performance in firms with strong corporate governance and high growth opportunity, implying that the tournament effect exists in Chinese firms.

Control systems Literature on control systems mainly discusses the combination of Chinese and Western countries' systems during the period in which joint ventures were very popular. Chow et al. (1999) provide evidence that differences between Chinese and Anglo-American organizations in terms of informal information sharing is due to cultural inferences. Other literature insists that partner knowledge and specific asset investments are the determinants of control systems for US-China joint ventures. As well, an introduction to the adoption of Western management controls in Chinese state-owned enterprises is provided O'Connor et al. (2006), in which they discuss how political factors influence the organizational design of state-owned companies.

\section{Financial management and corporate governance}

We briefly review the literature on financial management and corporate governance in this section though these topics are not the main focus of this paper. Accounting is associated with financial management and corporate governance and therefore we briefly introduce the literature in accordance with our reference sample.

Financial management Literature on financial management includes the following aspects: financing decisions, investment decisions, payout policy, and cash holdings. However, these studies are not mutually exclusive.

Literature on financial decisions and investment decisions first discuss the financing environment and its effect on corporate financial and investment decisions. Allen et al. (2005) find that though the financial system is less developed in China, the economy's growth is mostly driven by alternative financial channels and governance mechanisms such as reputation and relationships. Another paper by Cull and Xu (2005) shows that property rights which proxy for expropriation risk and contract enforcement play a critical role in reinvestment decisions. The literature then focuses on financial structure and financial distress. Financial structure mostly refers to leverage decisions and $\mathrm{Lu}$ and Xin (1998) provide the first empirical results about the determinants of leverage in 
China, which show that industry factors drive the differences in leverage. Subsequently, it is found that information asymmetry can explain leverage decisions in China while that managerial ownership is another determinant of leverage. A survey shows that there are equity preferences for the financial decisions of Chinese firms, which may explain the changes in leverage in China. Studies on financial distress aim to provide the model for predicting financial distress (Chen 1999; Chen and Chen 2000). Finally, investment decisions, especially investment efficiency, are mostly influenced by information asymmetry, financial development and corporate governance (Tang et al. 2007).

Payout policy and cash holding decisions are usually associated with each other. Thus, most studies investigate the determinant of payout policy and its effects from 1998 to 2007. Free cash flow could explain the dividend decisions of Chinese firms. Consistent with this, dividend decisions are affected by ownership structure and the entrenchment effect of cash holdings decreased with the implementation of the Split-Share Reform in China. Meanwhile, by investigating the determinants of the malicious dividends, evidence is presented that the separation of control rights and cash flow rights could exacerbate the distribution of malicious dividends but institutional investors could impede them.

Corporate governance The corporate governance literature mainly discusses investor protection in China, a special topic for emerging markets. Some focus on Type II agency costs, the agency conflicts between minority shareholders and controlling shareholders, while others investigate the effect of ownership structure and political connections.

Evidence on Type II agency costs shows that there is a tunneling effect of controlling shareholders rather than an alignment effect, such as related party transactions, and inappropriate dividends. Jiang and Yue (2005) provide other evidence that the cash occupation of controlling shareholders can be detrimental to corporate performance and excess stock returns. However, there is a U-shaped association between ownership concentration and benefits transfer, implying that controlling shareholders have both entrenchment and alignment effects.

Studies on ownership structure show that insider control is severe in state-owned companies resulting in a "59-year-old" phenomenon and perquisite consumption (Huang 2000). Further evidence shows that equity balance may have a monitoring effect. Meanwhile, a review on the association between ownership structure and firm value suggests some topics related with ownership structure for future research.

Since the government plays an important role in China's economy, research on the effect of political connections on corporate behavior emerged in the literature. With China's partially privatized firms, Fan et al. (2007) find that firms with politically connected CEOs underperform those without politically connected CEOs and have poorer three-year post-IPO earnings growth, sales growth and changes in returns on sales.

\section{Auditing}

Literature on auditing research can be divided into four areas during the 1998-2007 period, namely audit quality, audit fees, audit demand, and internal control. For a more detailed review on auditing during this period, please see Wu and Liu (2008). 
Audit quality The audit quality literature mainly investigates the determinants of audit quality, especially the supply side, that is, the characteristics of auditors. Yuan and Li (2003) find that auditors have no impact on earnings management, which suggests low audit quality. Consistent with the above evidence, it is also provided that the Big 4 cannot increase audit quality. With corporate tax audits, Chan and Mo (2000) provide evidence that tax audits do not restrain tax noncompliance. Moreover, Liu and Zhou (2007) report that firms with Big 4 auditors exhibit lower earnings conservatism which results from the determinants of legal risk for audit quality. However, other studies show that earnings management is associated with modified audit opinions and audit quality is affected by Big 4 auditors, Big 10 auditors, and audit tenure (Chen and Xia 2006; Liu 2006), implying that reputational concern plays an important role in audit supply. In addition, some studies focus on the consequences of audit quality and a significantly negative association between modified audit opinions and cumulative abnormal returns is provided. As well, $\mathrm{Hu}$ and Tang (2007) find consistent evidence with bank loan interest. Evidence is shown that modified audit opinions are related to change in auditors in the next fiscal year, suggesting that there is opinion shopping incentives among clients.

Audit demand The audit demand literature discusses whether there is high audit demand in China. Due to government intervention, Zhu et al. (2004) find that audit demand is lower in China. As well, many studies provide evidence that ownership structure and investor protection are associated with audit demand proxied by high quality auditors (Sun and Cao 2004; Zeng and Ye 2005). Thus, the demand for high quality audit results from both institutions and firm characteristics. Other literature focuses on independent auditors which is also related to audit demand. Wang and Chen (2001) find that the organizational reform of audit firms may improve auditor independence. However, some studies show that auditor independence is lower in China due to low audit demand. Evidence shows that the increase in modified reports is followed by a decline in audit market share (DeFond et al. 1999), that there is a preference for local auditors who have greater economic dependence on local clients and are subject to more political influence from local governments (Chan et al. 2006), and that there is collusion between clients and auditors (Lei 2004).

Audit fee The audit fee literature investigates the determinants of audit fees, where evidence is provided that firm size, corporate governance, operating complexity, listing location, regulation, and Big 5 auditors are associated with audit fees (Wu 2003; Liu et al. 2003; Li and Wu 2004). Moreover, the relation between audit fees and audit opinions are discussed by Wu (2003). They provide evidence that higher audit fees are associated with negative audit opinions, suggesting that audit fees reflect audit effort.

Internal control The internal control literature explores how to construct internal control systems and the effectiveness of internal control in China. Internal control systems are internal monitoring mechanisms and should cover the following aspects: control environment, risk evaluation, control activities, information communication, and internal monitoring which is consistent with COSO. Further, internal audit is an 
auxiliary mechanism for internal control systems. Li et al. (2003) investigate the information disclosure of internal control in China, in which they show that information disclosure of internal control contains less efficient information and should be enhanced with auditing. For the effect of internal control on innovation, internal control is divided into strategic internal control and financial internal control where they provide evidence that the former is positively related with disruptive innovation and negatively related with gradual innovation while the latter is reversed. As well, though there are audit committees in Chinese listed firms, audit committees are less effective which may result from the establishment of audit committees without endogenous power (Yang and Xu 2004). However, literature provides further evidence that audit committees may impede accounting restatement and fraud.

\section{Accounting research during 2008-2018}

Accounting research flourished in China from 2008 to 2018 as accounting topics gradually expanded into different academic areas and many articles on Chinese accounting topics were published in top-tier accounting and finance journals. Issues discussed in the accounting literature are broad and include financial accounting, managerial accounting, financial management and corporate governance, auditing, and tax, which we review in the following.

\section{Financial accounting}

The reform of accounting standards in 2006 is one of the most important issues for financial accounting research during the 2008-2018 period, especially for the introduction of fair value accounting. Then, similar to the accounting literature published during the 1998-2007 period, information disclosure and information quality are still popular issues. Moreover, literature on the information environment rose due to the increasing role of analysts and media as well as data availability. In addition, several studies discuss the effect of ideological and macroeconomic factors on the accounting profession, raising some questions for future research (Jiang and Rao 2011).

Accounting standards Literature on accounting standards in China from 2008 to 2018 mainly investigates the effectiveness of the China accounting standards reform in 2006 which converged with the IFRS. The feature of the new accounting standards is that fair value accounting is introduced for measurement attributes. In general, the value relevance of accounting information is increased with the new adoption of accounting standards in 2006. However, they also provide evidence that the increased value relevance of accounting information is due to comprehensive measurement rather than the simple adoption of fair value accounting. Subsequently, He et al. (2012) show that there are some unintended consequences to fair value accounting in China, including the increased incentive of using fair value accounting to meet regulatory earnings targets and avoid reporting a loss when exchanging nonfinancial assets in debt restructuring. The development of accounting regulations for foreign invested firms in China is introduced andreflects how to mediate the adaptation and transformation of Western accounting ideas in China. 
Meanwhile, some studies discuss the nature of fair value accounting and compare it with historical accounting. Evidence is shown that the accounting information under fair value accounting is an estimate rather than exact which may bias the information disclosed in financial statements. As well, it is suggested that accounting information obtained under historical accounting should be disclosed in financial statements while accounting information under fair value accounting can be disclosed in financial statement notes. Literature discusses the pro-cyclical effect of fair value accounting and provides some suggestions to cope with the risks of fair value accounting.

Information disclosure Some literature about information disclosure focuses on the disclosure behavior with market-based measures including stock price synchronicity and stock price crash risk while others investigate the disclosure behavior of management forecasts or other non-financial information disclosure which have semi-mandatory disclosure requirements in China. Meanwhile, there are also studies that investigate the information asymmetry in China in different settings.

Stock price synchronicity is a measurement for information disclosure, which reflects whether stock prices contain firm-specific information (Jin and Myers 2006). However, there is a debate on whether stock price synchronicity reflects firm-specific information or noise. Consistent with the wider debate, the evidence in China also contradicts each other. A positive association between information asymmetry and stock price synchronicity is found. But evidence is provided that foreign ownership and audit quality are inversely related with stock price synchronicity and that the amount of earnings information reflected in stock returns is lower for firms with high synchronicity. Stock price crash risk is another measurement for information disclosure, which reflects managers' incentives to hoard bad news. Consistent with this view, Chen and Zhang (2009) find that heterogeneous beliefs may induce stock price crashes. Then evidence is presented that the herding of institutional investors may increase the incentive for bad news hoarding increasing stock price crash risk (Xu et al. 2013) while internal control (Ye et al. 2015), and the political ranks in China may mitigate the incentive of withholding bad news resulting in less crash risk.

For the disclosure behavior of management forecasts, Quan and Wu (2010) show that the attention of investors may influence the timing of management earnings forecasts. Evidence is shown that the disclosure of management forecasts is a signal to investors. Aside from financial information disclosure, studies also investigate the disclosure of non-financial information including environmental information, corporate social responsibility (CSR) information, etc. The disclosure of financial information and non-financial information is compared and evidence is provided that the Split-Share Reform only has an effect on non-financial information disclosure. Environmental information is disclosed under pressure from government and regulators while corporate governance as an internal factor also influences the disclosure of environmental information. Meanwhile, CSR information disclosure is discussed as well. Studies find that CSR and financial performance are interactive in that good CSR may improve financial performance and firms will engage in more CSR activities with good financial performance. However, evidence provided by Chen et al. (2018) reports that the mandatory disclosure of CSR has a negative impact on financial performance though environmental 
indicators such as industrial wastewater and $\mathrm{SO}_{2}$ emission levels also decrease. They suggest that mandatory CSR disclosure changes firm disclosure behavior and brings in positive externalities at the expense of shareholders.

In addition, the literature also shows the information asymmetry problems in China in different settings. Chan et al. (2008) provide evidence that the price discount between A-shares and B-shares is mostly due to bid-ask spread, a component of adverse selection. Tang (2011) attributes the price discount phenomenon to disclosure disparity which may create differences in investors' information precision across A- and B-shares. Information asymmetry, measured by PIN, may induce financial constraints and have a negative effect on investment, providing evidence on how information asymmetry affects corporate financial decisions.

Information quality Literature on information quality in China during the 2008-2018 period mainly focuses on earnings management and accounting conservatism in China. The former mostly investigates Type I and Type II agency conflicts while the latter explores the contracting role of accounting conservatism between creditors and companies. Type I agency cost is the conflict between shareholders and managers, and Type II agency cost is the conflict between controlling shareholders and minority shareholders.

Earnings management literature investigates the determinants and consequences of earnings manipulations. Evidence shows that lawsuits, fair value accounting (Mao and Dai 2009), stock options, seasoned equity offerings, tax avoidance incentives, insider sales, government subsidies, CEO turnover, performance commitment contracts (Hou et al. 2015), and less scrutinized reverse merger processes (Chen et al. 2016b) will increase managers' incentive to engage in earnings manipulations. However, strong corporate governance, which is measured by ownership structure, board structure, and institutional investors can mitigate the incentive of manipulating earnings. Other studies explore the consequences of earnings management and find that earnings management may result in bank loan loss, investment inefficiency, and negative future performance. As well, Li and Wang (2011) find that information quality can mitigate the negative effect of monetary tightness on bank loans. Meanwhile, some of the above studies compare the differences between accrual-based and real earnings management to provide more detailed evidence on earnings management when exploring the determinants and consequences of earnings management. They argue that real earnings management may be more harmful to firm operations. In addition, the efficiency of the model for calculating discretionary accruals is investigated, where it is suggested that the cross-sectional modified Jones model may be more efficient in China.

Accounting conservatism is the timeliness of loss recognition and profit recognition, which is more important for creditors. Zhu and Li (2008) and Chen et al. (2010a) provide evidence that state-owned companies adopt less conservative accounting methods than non-state-owned ones due to less concern with downside risk for state-owned companies and state-owned banks demanding less conservative accounting information. Mao and Dai (2009) provide evidence that the adoption of fair value accounting could decrease accounting conservatism and leave more space for earnings manipulation and literature shows accounting conservatism appears as a U-shaped curve in the life cycle of enterprises. 
Moreover, accounting restatements and scandals are also discussed. The characteristics of management teams, such as management team size, gender diversity, and age can influence accounting restatements based on the upper echelons theory. One article classify corporate scandals into political scandals (associated with the destruction of political ties), market scandals (market credibility) and mixed scandals (both political ties and market credibility), in which they document that political scandals lead to more negative stock returns than market scandals and the association is primarily driven by firms that rely more on political networks. As well, evidence is provided that political scandals and mixed scandals are associated with a larger decrease in operating performance and financing from state-owned banks. For the penalty for fraud, Chen et al. (2012a) find that punishment is timely, selective and regulators may be more likely to punish fraud before starting of their new tenure.

Information environment Analysts, media coverage, and regulation are important factors in the information reporting environment. Thus, we review the literature on information environment in these three areas.

With the financial development, analysts play a more important role in equity markets. The first question is whether analysts can provide more efficient forecasts and enhance market efficiency. Yue and Lin (2008) provide evidence that analysts' yearly forecasts may be more accurate. As well, analyst coverage is an external governance mechanism which can mitigate the effect of information opacity on stock price crash. Consistent with this view, analyst coverage may mitigate bubbles by coordinating investors' beliefs and reducing dispersion. With data on analysts' corporate site visits, literature shows that site visits can facilitate analysts' information acquisition which may make analyst forecasts more accurate and mitigate the bias of nonlocal analysts. Insiders will time their transactions with the news disclosed in private meetings with analysts, implying that site visits are informative (Bowen et al. 2018). However, there are also studies that argue that analysts are biased. Affiliated analysts, who are working in the investment banks of IPO firms, are more optimistic which enlarges stock price drops after an IPO. Moreover, the social connections between analysts and investors affect investor reactions to analyst recommendations which may exacerbate market segmentation between A-shares and $\mathrm{H}$-shares. As well, several studies investigate the factors that could improve analyst forecast accuracy, where evidence is shown that earnings quality (Li and Jia 2009), management earnings forecasts (Wang and Wang 2012) and CSR information can make analyst forecasts more accurate.

Another part of the literature discusses the role of media coverage on the information environment. Literature raise two views on media coverage: the monitoring effect and the market pressure effect, in which they suggest that media coverage can exert pressure on companies which may induce accrual-based earnings management to beat market expectations. However, Luo and Du (2014) argue that media coverage can serve as an informal governance mechanism, and they find that media coverage can decrease crash risk. Further evidence is provided that only the market-oriented media plays a governance role due to their operating efficiency and independence.

The information environment is also affected by regulation. Looking at the information disclosure rating issued by the Shenzhen Stock Exchange, strong corporate 
governance can induce better information disclosure ratings while Quan and Wu (2010) show that higher information disclosure ratings can result in less volatile performance. In addition, several studies investigate the effect of political factors on the information environment. Evidence is shown that politicians with promotion incentives have an incentive to temporarily suppress the flow of negative information.

\section{Managerial accounting}

The managerial accounting literature in China during 2008-2018 mainly concentrates on compensation contracts. Few studies focus on performance evaluation and control systems due to lack of data availability.

Compensation contracts Many papers on compensation contracts were published in China from 2008 to 2018. The issues studied are diversified and include the determinants of compensation, pay-performance sensitivity, pay gap, stock options, and the consequences of compensation.

Literature on the determinants of compensation provides evidence that management power (Quan et al. 2010), controlling rights (Wu and Wu 2010), market-oriented processes, media coverage (Yang and Zhao 2012), and ownership structure (Quan et al. 2010) are the determinants of compensation. Strong management can design contracts discretionarily and has no incentive to manipulate earnings to get higher monetary compensation while weak management focuses more on monetary compensation and engages in earnings management to beat targets. Evidence in Quan and Wu (2010) is consistent with the above evidence, whereby they document that managers from central state-owned companies prefer non-monetary compensation while local state-owned companies prefer monetary compensation. As well, Wu and Wu (2010) provide similar evidence from the perspective of controlling rights. Perks are substituted by monetary compensation with the development of market-oriented reforms. Yang and Zhao (2012) show that media coverage is an efficient mechanism to govern the discretion in compensation contract design. Evidence shows that ownership structure has a significant effect on compensation and state-owned companies pay more to their employees.

The existence of pay-performance sensitivity is documented, in which he finds that compensation is sticky. Subsequently, evidence is provided that market-oriented processes, and independent directors' board network centrality (Chen and Xie 2012) can increase pay-performance sensitivity. However, it is documented that political intervention may have a negative impact on pay-performance sensitivity.

Literature on the consequences of compensation mainly investigate whether compensation can mitigate or increase agency costs. CEO compensation is positively associated with corporate innovation, suggesting that $\mathrm{CEO}$ compensation can stimulate innovation with decreased agency costs. Similarly, the restriction on compensation can induce corruption, implying that compensation restriction may result in higher agency costs. Moreover, Jiang and Huang (2011) show that CEO compensation and leverage can substitute for each other when determining firm value.

Pay gap is another sub-topic in the compensation literature which focuses on the compensation structure in firms. Zhang (2008) provides evidence that the pay gap 
between management team members has a negative impact on future performance, but pay gaps between managers and employees has no impact. However, inconsistent with Zhang (2008), another evidence is found that pay gaps between managers and employees in state-owned companies can have a motivation effect, resulting in better future performance. In addition, positive abnormal compensation is only positively associated with performance in non-state-owned companies, suggesting that abnormal compensation may only have an effect in non-state-owned companies, where abnormal compensation is measured with OLS regression.

Literature on stock options explores the determinants of issuing stock options and the effectiveness of stock options. Stock options not only serve as an incentive, but also as a method for distributing benefits. Further, Lyu et al. (2011) find that firms with weak corporate governance are more likely to grant stock options, implying that the beneficial effect of stock options is prominent. As well, studies investigating the effectiveness of stock options show that stock options are effective in state-owned companies with the increase of controlling shareholders but are ineffective in non-state-owned companies. Consistent with this, Chen et al. (2013) provide similar evidence showing that stock options granted to directors in state-controlled Red Chip firms are not genuine compensation, but are a response to the demands of foreign investors. However, other studies provide evidence that stock options can improve investment efficiency and innovation, reducing agency costs.

Performance evaluation and control systems Aside from the discussion of compensation contracts, several studies investigate performance evaluation and management control systems in China during the 2008-2018 period. Du et al. (2012) show that political connection, the geographic proximity to the State-Owned Assets Supervision and Administration Commission of China (SASAC), and the political rank of state-owned companies can influence performance evaluation. Then, adopting the new performance measures EVA (economic value added) to substitute for ROE (return on equity) can motivate supervisors to consider personal preferences in subjective adjustment decisions.

For control systems, with an experiment, Chinese participants do have an accountability demand for information which is at least as high as that of U.S. participants. Meanwhile, it is illustrated that how the ideological shift toward enhanced shareholder orientation influences the development of management control practices in Chinese state-owned companies.

\section{Financial management and corporate governance}

The financial management and corporate governance literature in China during the 2008-2018 period covers the following topics: financing and investment decisions, investor protection, and board structure. Aside from these topics, privatization is also an important topic since the Split Share Structure Reform of 2006 and many studies investigate the effect of this privatization reform.

Financing and investment decisions Literature on financing decisions discusses financial constraints, bank loan financing, IPO and SEO. Internal capital markets can 
mitigate financial constraints, especially in state-owned companies, suggesting that internal capital markets are efficient in China. Tang and $\mathrm{Xu}$ (2010) examine the financial constraints of innovation and find that $\mathrm{R} \& \mathrm{D}$ expenditure relies more on internal capital. Consistent with Tang and $\mathrm{Xu}$ (2010), there are severe financial constraints for R\&D expenditure in China. Evidence provided by Lin and Ye (2018) shows that foreign direct investment firms will provide more trade credit than local firms during tight credit periods so as to mitigate the financial constraints caused by global liquidity shocks.

The bank loan financing literature mainly explores the determinants of bank loans and the effectiveness of bank loans. Corporate insurance determines firms' debt capacity and the cost of debt. Further, Zhang and Li (2012) show that social capital is positively associated with bank loan financing. For the effectiveness of bank loans, firms with bank financing grow faster than those without bank financing, implying that bank loans are associated with the fast growth of China's economy. However, evidence is shown that stock returns response negatively to bank loan announcements, suggesting that bank loan decisions are inefficient.

The IPO literature investigates the role of government in firms' IPO decisions. The government will consider the likelihood and severity of scandals in different regions and then allocate the IPO quota accordingly, implying that the spillover effect in regions may be like an implicit contract. Subsequently, evidence provided by Hung et al. (2012) and Piotroski and Zhang (2014) shows that IPO decisions are mostly driven by the promotion incentives of local politicians. Shi et al. (2018) find that though the CSRC uses IPOs to support the market, sizable IPOs depress the market price which seems ineffective. Except for being listed through IPO, Lee et al. (2015) investigate the long-term performance of reverse-merger firms, which is cheaper and quicker than IPOs, showing that Chinese reverse-merger firms tend to be more mature and less speculative, and outperform their matched peers.

SEO literature focuses on whether issue price discounts are due to the tunneling effect. The opportunism of controlling shareholders is the main determinant of price discount in SEO decisions, where the SEO is used as a way to transfer benefits. Another study not only confirms the above findings, but also show that information asymmetry is another factor that influences price discounts.

Literature on investment mainly focuses on the efficiency of investments. The deviation from optimal investment is large, suggesting that investment inefficiency is severe in Chinese listed firmsand over-investment may result from investor sentiment. Evidence is also suggested that ownership structure is a primary institutional factor affecting corporate investment where the derived discount rate for non-state-owned firms is higher than for state-owned firms. Ang et al. (2015) suggest that trust is important when making investment decisions demonstrated by the case of foreign high-tech companies investing in China since trust can mitigate the risk of expropriation of their intellectual property.

Investor protection Literature on investor protection in China during the 2008-2018 period discusses the Type II agency costs between controlling shareholders and minority shareholders. Jian and Wong (2010) provide evidence that listed firms prop up earnings by using abnormal related sales to controlling shareholders with cash and 
non-cash transfers. Transactions with cash transfer are associated with future related lending from listed firms back to controlling shareholders while non-cash transfer is found to be associated with accruals earnings management. Jiang et al. (2010) find that controlling shareholders expropriate benefit through inter-corporate loans, suggesting that tunneling is more severe in China's weak investor protection environment. Consistent with Jiang et al. (2010), Tang et al. (2008) show that related-party guarantee is another way controlling shareholders exploit private benefit.

Moreover, the diversity of blockholders could mitigate the problem of tunneling. Evidence in Chen et al. (2013) shows that regulations that improve minority shareholders protection can deter value-decreasing corporate decisions and increase the likelihood of large abnormal returns around the announcement of the regulations.

Board structure Literature on board structure explores the effectiveness of different board structures. Jiang et al. (2016) focus on the role of independent directors, but their evidence is contradictory. Some literature argues that independent directors have no significant effect on firm performance since there are fewer reputation concerns and less labor market pressure in China. However, Jiang et al. (2016) provide evidence that independent directors' consideration of reputational loss could make them more likely to veto proposals. In addition, Giannetti et al. (2015) investigate the introduction of talented emigrants, showing that performance increased after hiring directors with foreign experience.

Privatization Privatization is a popular issue in emerging markets and China issued a Split Share Structure Reform in 2006 accompanied with market-oriented reforms. Thus, several studies investigate whether these privatization reforms are effective.

Chen et al. (2008) find that there is a positive impact on performance when control rights are passed to a private entity and stock markets respond positively to this change, suggesting that the reform enhances corporate performance efficiency. Consistent with Chen et al. (2008), Liao et al. (2014) provide evidence that the expectation of privatization boosts the output, profits and employment of state-owned companies. But some evidence do not find that operating efficiency and corporate governance are improved with the reform.

Then, several studies focus on the governance effect of the privatization. Chen et al. (2012b) show that cash holdings decreased after the privatization reform, especially for firms with weak corporate governance. Hope et al. (2018) show further evidence that performance improves with privatization due to the governance role of outside blockholders' exit threats. Based on intellectual property rights, Fang et al. (2017b) show that privatization can enhance the protection of intellectual property rights, resulting in increased innovation.

Finally, some studies discuss the compensation which is proposed in exchange for the listing rights of firms' shares during the privatization reform. Firth et al. (2010) show that state ownership is positively associated with final compensation ratios while mutual fund ownership is negative, implying that state shareholders have incentives to complete the reform quickly and exert political pressure on mutual funds to accept their terms. Other evidence provided by Li et al. (2011) finds that the size of the 
compensation is positively correlated with gains from risk sharing and the price impact of more shares coming on the market following the reform.

\section{Auditing}

The auditing literature in China during the 2008-2018 period mostly investigates the following topics: audit quality, audit demand, audit supply and internal control. However, we should note that these topics are related with each other. For example, audit quality is influenced by both audit demand and audit supply. Thus, we will first briefly introduce the definitions of audit quality and the proxies for audit quality used in the literature. Then, the literature on audit demand and audit supply will be discussed. Finally, we review the literature on internal control as there are many regulations on internal control that were implemented during this period, including C-SOX and the Internal Control Guidelines.

Audit quality In this section, we will review the proxies for audit quality and the consequences of audit quality. The literature on the effect of audit demand and audit supply on audit quality will be discussed in the following two sections.

The measurements for audit quality can be classified into input measurement and output measurement. The input measures mostly refers to auditor characteristics, including the Big 4, industry expertise (Liu et al. 2010), and audit hours (Gong et al. 2016). The output measures include modified audit opinion (Chen et al. 2010b; Chen et al. 2011; Gul et al. 2013), discretionary accruals (Gul et al. 2013; Li et al. 2017a), below-the-line items (Gul et al. 2013), small profits (Gul et al. 2013), and sanctions against auditors. However, the above proxies for audit quality cannot measure the process of auditing, which may be biased due to the effect of client characteristics. To solve this problem, Lennox et al. (2016) provide evidence that audit adjustments are associated with high earnings quality, suggesting that audit adjustments could reflect the audit quality of the auditing process.

Meanwhile, the existing literature also investigates the consequences of audit quality. Audit quality measured by audit opinion can affect financial constraints and enhance the associate between accounting information and investment efficiency. Moreover, regarding equity markets, evidence shows that high audit quality can reduce the cost of equity (Chen et al. 2011) and mitigate stock price crash risk. For the debt market, it is found that audit quality is positively associated with the cost of debt.

Audit demand The audit demand literature mostly focuses on which factors affect the demand for auditing since auditing is a way for managers to reduce agency costs. However, most studies in China suggest that there is low audit demand in China due to the weak institutional environment.

First, state ownership is associated with low audit demand, where Wang et al. (2008) provide evidence that local state-owned firms are more likely to hire small auditors within the same region, especially in less developed regions, which can be explained by state-owned firms' lack of demand for large auditors, small local auditors' superior local knowledge and state-owned firms' collusion incentives. Consistent with this, Chen et al. (2010b) find that the propensity to issue modified audit opinions is positively 
associated with client importance with the improvement of the institutional environment. However, Liu (2009) suggests that upward earnings management of state-owned firms are more likely to receive modified audit opinions compared with non-state-owned firms.

Then, several studies concentrate on the effect of political connections on audit demand. Evidence in Du and Zhou (2010) shows that non-state-owned firms with political connections are more likely to hire non-Big 10 auditors, suggesting that political connections may reduce audit demand. Other evidence implies that the governance role of auditors is influenced by political connections.

Finally, other studies investigate audit demand in China based on different perspectives. Ke et al. (2015) find that the Big 4 assign their less experienced partners to firms that are listed only in Chinese mainland compared with clients cross-listed in Chinese Hong Kong and these less experienced auditors are less likely to issue modified audit opinions and charge lower audit fees, implying that the weak institutional environment in Chinese mainland may result in low audit demand. Chen et al. (2016a) show that companies successfully engage in partner-level opinion shopping, where they find that the propensity of receiving clean audit opinions is higher with the incoming partners. However, Fang et al. (2017a) provide evidence that there is high audit demand for Chinese group firms which are more likely to appoint Big 10 auditors resulting in high earnings disclosure quality, high valuation implications of related-party transactions and cheap equity financing because controlling shareholders have incentives to improve external financial reporting processes.

Audit supply Audit supply is impacted by the auditors' incentives and ability to provide high audit services. Incentives are mostly related to auditor independence while ability is associated with competence. Hence, the following will review the literature according to auditor independence and competence.

Literature on auditor independence investigates the factors that influence auditor independence. Evidence is provided that auditor independence in China is positively associated with ethical culture in an audit firm, audit firm mergers (Gong et al. 2016), the unlimited liability form of an audit firm, and mandatory rotation (Lennox et al. 2014) and negatively related to client importance (Chen et al. 2010b), the political connections of audit firms (Yang 2013), low balling, and the school ties between auditors and client executives.

Evidence on auditor competence mostly supports the notion that professional expertise could improve audit supply and benefit audit quality. Liu et al. (2010) provide direct evidence that auditors with industry expertise could mitigate accounting fraud and stock price crash risks. Gul et al. (2013) find that individual auditors have significant effects on audit quality which can be partially explained by auditor characteristics such as educational background, Big $\mathrm{N}$ firm experience, rank in the audit firm and political affiliation. Li et al. (2017a) also confirm the role of competence on audit quality, where they find that low audit quality at the individual level has contagion effects. Moreover, several studies examine how auditors respond to complex situations to ascertain the competence of auditors. Bo and Wu (2011) find that auditors ask higher audit fees and issue modified audit opinions in response to audit risks. As well, product 
market competition is related to audit fees and auditors will make more downward audit adjustments before stock-financed acquisitions, suggesting that auditors' decisions result from the evaluation of audit risks. In addition, auditor-client negotiations affect the outcomes of auditing.

Internal control With the enforcement of C-SOX and the Guideline for Internal Control, internal control was a popular topic in China during the 2008-2018 period. Existing literature mainly investigates the disclosure of internal control, the determinants of internal control quality, and its consequences.

Literature on internal control disclosure first investigates why firms disclose internal control information voluntarily since the mandatory disclosure of internal control is only required for firms listed in main board A-shares from 2012. Yang and Wang (2008) find that the incentive of voluntarily disclosing internal control information is weak and further evidence is provided that voluntary disclosure of internal control has a signaling effect. Subsequently, operating complexity, auditor turnover, and restatement are related to the disclosure of internal control weakness.

Regarding the determinants of internal control quality, an evaluation system for internal control quality using the analytic hierarchy process (AHP) is provided. As well, another evaluation system is presented, which suggests that it is necessary to evaluate internal control quality by regulation department. Empirical evidence reports that corporate governance factors including board size, the duality of CEO and chairman, audit committee, and risk preferences are associated with internal control quality and local state-owned companies have weak internal control quality and external institutional environments such as marketization could mitigate the effect. Moreover, a survey finds that firm size, financial conditions, decentralization, corporate culture and ethics are the determinants of internal control quality.

The consequences of internal control are discussed in relation to different areas, such as information quality, financial decisions, and corporate governance. Most of the existing literature supports the idea that internal control has a positive effect on information quality measured by discretionary accrual and earnings response coefficients. Meanwhile, evidence also confirms that investment efficiency is improved with internal control. Finally, internal control can restrain the tunneling of controlling shareholders, especially for firms with low audit quality, suggesting that internal control can serve as an internal governance mechanism to lower agency costs.

Tax

Accounting literature related to tax mostly focuses on tax benefits and tax avoidance. The former describes subsidies provided through tax breaks and the latter is also called tax aggressiveness and defined as the reduction of explicit taxes. We review the literature on tax benefits and tax avoidance in the following. An exception to these categories is $\mathrm{Xu}$ and Xu's (2016) study, which examines the tax reform launched by the Nationalist Government in China during 1928-1949 as a case study to enrich the understanding of the relationship between taxation and nation building. 
Tax benefits Evidence is shown that managers with political ties receive more tax benefits (Wu et al. 2009) and the tax burden of state-ownership is higher for state-owned firms, which decreases firm value (Wu 2009). Lee et al. (2014) examine the value relevance of government subsidies and find that subsidies granted through more transparent and fair channels, such as tax-based subsidies, are more value relevant. Li et al. (2017b) provide evidence that a reduction in individual investors' dividend tax rate can increase dividend payout and investors respond to this reform by reducing their trading activities.

Tax avoidance Evidence is provided that tax avoidance can induce negative consequences including stock price crash risk (Jiang 2013) and investment inefficiency (Liu and Ye 2013), suggesting that tax avoidance may exert information asymmetry. Chan et al. (2010) show that the adoption of IFRS encourages tax avoidance since a departure from a tax-based accounting system can decrease book-tax conformity which is informative of tax noncompliance. Further, Tang et al. (2017) find that the conflicts between central and local governments arising from the tax sharing reform in 2002 has led to more tax avoidance of local government-controlled firms and tax avoidance of local government controlled firms is positively associated with local fiscal deficits.

\section{Conclusions and future suggestions}

Through the above review of accounting research in China during the past four decades, we can conclude that Chinese accounting research has contributed to both academic knowledge and practice. For academics, firstly, research methodologies have improved during the past 40 years, especially in the most recent two decades. With the development of capital markets and increased data availability, research methods have shifted from normative research to positive research, which is currently the most popular accounting research method and provides more convincing evidence to explain business activities. Second, research topics have gradually diversified and new topics have emerged. Generally, in the first two decades, most studies investigate the definition, concepts or fundamentals of accounting factors. But the relationship between accounting factors are examined in the most recent two decades, which not only explore the association between accounting factors, but also include the factors of economics, management, politics, sociology, psychology and so on. The introduction of other academic disciplines broadens the view of accounting research in China and complements the accounting literature. Moreover, new research topics have increased with the growth of the economy since economic growth brings in new research questions and data availability has increased with technology progress. For example, though Chinese stock markets were established in 1990, financial institutions, such as analysts, played a more important role in the 2000s. Thus, much literature investigates the impact of analysts since the 2000s. Third, Chinese accounting research complements international research, where China provides a unique setting to investigate emerging market issues such as government intervention, investor protection and so on. As well, with unique auditing data, including partner-level information and audit adjustments, several fundamental issues in auditing are examined, which contributes to the international accounting literature. Table 2 provides a brief description of articles published in Chinese and 
Table 2 Number of articles published in Chinese and international journals for each topic in the past two decades

\begin{tabular}{|c|c|c|c|}
\hline & & $\begin{array}{l}\text { Chinese } \\
\text { journals }\end{array}$ & $\begin{array}{l}\text { International } \\
\text { journals }\end{array}$ \\
\hline \multicolumn{4}{|l|}{ 1998-2007 } \\
\hline \multirow[t]{4}{*}{ Financial Accounting } & Accounting Standards & 3 & 1 \\
\hline & Information Disclosure & 19 & 0 \\
\hline & Information Quality & 26 & 3 \\
\hline & Information Environment & 3 & 0 \\
\hline \multirow[t]{3}{*}{ Managerial Accounting } & Compensation Contract & 15 & 0 \\
\hline & Control Systems & 0 & 3 \\
\hline & Performance Evaluation & 1 & 0 \\
\hline \multirow{2}{*}{$\begin{array}{l}\text { Financial Management and } \\
\text { Corporate Governance }\end{array}$} & Financial Management & 13 & 2 \\
\hline & Corporate Governance & 8 & 1 \\
\hline \multirow[t]{4}{*}{ Auditing } & Audit Quality & 13 & 2 \\
\hline & Audit Demand & 7 & 2 \\
\hline & Audit Fee & 5 & 0 \\
\hline & Internal Control & 8 & 0 \\
\hline \multicolumn{4}{|l|}{ 2008-2018 } \\
\hline \multirow[t]{4}{*}{ Financial Accounting } & Accounting Standards & 5 & 4 \\
\hline & Information Disclosure & 15 & 5 \\
\hline & Information Quality & 23 & 4 \\
\hline & Information Environment & 9 & 8 \\
\hline \multirow[t]{3}{*}{ Managerial Accounting } & Compensation Contract & 21 & 2 \\
\hline & Performance Evaluation & 0 & 3 \\
\hline & Control Systems & 0 & 1 \\
\hline \multirow{4}{*}{$\begin{array}{l}\text { Financial Management and } \\
\text { Corporate Governance }\end{array}$} & Financing \& Investment Decisions & 9 & 10 \\
\hline & Investor Protection & 4 & 15 \\
\hline & Board Structure & 1 & 2 \\
\hline & Privatization & 0 & 7 \\
\hline \multirow[t]{4}{*}{ Auditing } & Audit Quality & 6 & 10 \\
\hline & Audit Demand & 3 & 6 \\
\hline & Audit Supply & 5 & 12 \\
\hline & Internal Control & 17 & 0 \\
\hline \multirow[t]{2}{*}{ Tax } & Tax Benefits & 2 & 3 \\
\hline & Tax Avoidance & 2 & 2 \\
\hline
\end{tabular}

Notes. This table briefly summarizes the number of articles published in recent decades for each topic to show trends in accounting research. However, it should be noted that most of the topics overlap with each other and it is difficult to strictly define a certain article as belonging to a specific topic

international journals for each of these topics in the recent two decades, to show the trend of accounting research in China and the comparison of topics published in Chinese journals and international journals.

For practice, first, accounting research in China during the past four decades contributes to the development of regulations. For example, many studies provide evidence that managers have incentives to manipulate earnings at the SEO regulation thresholds and this insight can contribute to the future revision of the regulations. Second, accounting research may be helpful for corporate decision-making including financing, 
investment, and compensation decisions, where corporate decisions can be made based on financial information. Finally, investors can make investment decisions based on the findings in Chinese accounting literature, in which they provide evidence on how investors react to certain financial information and provide inferences about the future. However, we can also recognize that there are still limitations for accounting research in China. Here we make some suggestions for future research directions.

First, it can be seen that Chinese accounting topics have attracted attention from international academics, and internationally published articles on Chinese accounting have increased significantly in the last 10 years. However, the topics published in international journals are not diversified, and mostly focus on investor protection and auditing in China because these two topics provide unique settings and data that are absent in developed economies especially in the US. Hence, we should try to promote research on a wider variety of topics and introduce the achievements of the economic growth of China to the world. For example, CSR disclosure is semi-mandatory in China, which is different from the US. Therefore, research on CSR disclosure in China would be beneficial for international research and practice, through which regulators in the US and other countries could use China's experience as a reference to develop a deeper understanding of CSR disclosure. Another example is the anti-corruption campaign characterized by the 8-point Austerity Rules, which constrains corruption in China. It would be relevant to investigate the consequences of the anti-corruption campaign, including the impact of political scandals, the prohibition to serve in companies and other requirements of corporate and politician behavior.

Second, the influential managerial accounting literature mostly focuses on compensation contracts, especially in the most recent two decades. However, managerial accounting covers many issues such as cost management, budgeting, control systems, performance evaluation, risk management, and so on. Thus, we strongly recommend broadening our view on managerial accounting research in China which not only complements the accounting literature, but also provides some guidance for managerial accounting practices.

Third, positive accounting research in the past two decades is mostly based on theories from economics, including information asymmetry, agency theory and so on. Fortunately, some studies try to use accounting information to address macro-economic issues, which provide future directions for accounting research. Thus, we suggest Chinese accounting research should pay more attention to how accounting affects macro-economics, through which we can not only develop new accounting theories, but also infer the role of accounting in macro-economics.

Finally, accounting research is closely connected with the wider environment. The accounting literature over the past four decades mostly explores how changes in the environment, such as regulations or market-oriented reforms, affect accounting and how accounting responds to the environment. For example, with the release of new accounting standards in 2006, most studies investigate whether the reform could make accounting information more value relevant. Therefore, we advise that future research could pay more attention to the change of environment in China, where economic growth provides a dynamic setting to explore the association between accounting and environment, including Big Data, AI, financial reform, the Belt and Road Initiative, environmental protection, the transition of business models, and so on. 


\section{Endnotes}

${ }^{1}$ Auditing can be divided into several areas such as internal audit, government audit, external audit, etc. This survey only focuses on financial statement audits. For the normative accounting research in the early stage, we only survey the accounting literature related to financial accounting and managerial accounting. This is because corporations were mostly state-owned until the reform of the shareholding system of stated-owned enterprises, resulting in lower financial statement audit demand before 1997. Thus, accounting research on financial statement audits in China was less important compared with financial accounting and managerial accounting at that time.

${ }^{2}$ We only include articles published before June 2018 since this review was written just after June 2018.

${ }^{3}$ The CSSCI (Chinese Social Sciences Citation Index) is an interdisciplinary citation index program in China in use since 1997. This citation database covers about 500 Chinese academic journals of humanities and social sciences. Many leading Chinese universities and institutes use CSSCI as a basis for the evaluation of academic achievements.

${ }^{4}$ Here we use the CNKI citation number to select the top-100 cited papers as a substitution because the CSSCI-index citation system was developed in 1997 and we cannot get the exact citation number of articles published before 1997. CNKI is the comprehensive China Integrated Knowledge Resources System, and includes journals, doctoral dissertations, masters' theses, proceedings, newspapers, yearbooks, e-books, patents, standards and so on. The citation number provided by CNKI not only contains CSSCI journals, but also includes non-CSSCI journals, doctoral dissertations, masters' theses, etc.

${ }^{5}$ China Accounting Review and China Accounting and Finance Review are published quarterly and the number of articles published are smaller than the other journals which are published monthly except for Nankai Business Review published bimonthly.

${ }^{6}$ Due to space limitation, we cannot include all the papers in the references. Please contact authors if needed.

${ }^{7}$ We review the literature on the association between information quality and auditing in the section of auditing.

\section{Acknowledgements}

We appreciate the helpful assistant provided by Zhanliao Chen, Can Wang, Hetao Sun, Ziqi Wang.

Funding

We appreciate the financial support of the Natural Science Foundation of China (Grant Number: 71772173; 71372162) and China Postdoctoral Science Foundation (Grant Number: 2017 M611087). All errors are our own.

Availability of data and materials

All the data and materials in this review could be found publicly.

Authors' contributions

HW raises the idea of this manuscript, makes the framework, and finishes the final revisions for this manuscript. KY reviews the accounting research during 1978-1997 and the literature about managerial accounting and tax during 1998-2018. KZ writes down the review about financial accounting, financial management and corporate governance, and auditing during 1998-2018 except for managerial accounting and tax.

Competing interests

None of the authors have any competing interests in the manuscript. 
Author details

${ }^{1}$ School of Business, Renmin University of China, Beijing, China. ${ }^{2}$ University of International Business and Economics, Beijing, China.

Received: 25 September 2018 Accepted: 26 November 2018

Published online: 27 December 2018

\section{References}

Allen, F., Qian, J., \& Qian, M. (2005). Law, finance, and economic growth in China. Journal of Financial Economics, 77(1), 57-116.

Ang, J. S., Cheng, Y., \& Wu, C. (2015). Trust, investment, and business contracting. Journal of Financial and Quantitative Analysis, 50(3), 569-595.

Bo XH, Wu LS. 薄仙慧, 吴联生. (2011). 㭆余管理、信息风险与审计意见(Earnings Management, Information Risk and Audit Opinion). 审计研究(Auditing Research), (1): 90-97.

Bowen, R. M., Dutta, S., Tang, S., \& Zhu, P. (2018). Inside the "black box" of private in-house meetings. Review of Accounting Studies, 23(2), 487-527.

Chan, K., Menkveld, A. J., \& Yang, Z. (2008). Information asymmetry and asset prices: Evidence from the China foreign share discount. The Journal of Finance, 63(1), 159-196.

Chan, K. H., \& Chow, L. (1997). An empirical study of tax audits in China on international transfer pricing. Journal of Accounting and Economics, 23(1), 83-112.

Chan, K. H., Lin, K. Z., \& Mo, P. L. (2010). Will a departure from tax-based accounting encourage tax noncompliance? Archival evidence from a transition economy. Journal of Accounting and Economics, 50(1), 58-73.

Chan, K. H., Lin, K. Z., \& Mo, P. L. L. (2006). A political-economic analysis of auditor reporting and auditor switches. Review of Accounting Studies, 11(1), 21-48.

Chan, K. H., \& Mo, P. L. L. (2000). Tax holidays and tax noncompliance: An empirical study of corporate tax audits in China's developing economy. The Accounting Review, 75(4), 469-484.

Chen, C. J., Su, X., \& Zhao, R. (2000b). An emerging market's reaction to initial modified audit opinions: Evidence from the Shanghai stock exchange. Contemporary Accounting Research, 17(3), 429-455.

Chen, DH, Jiang DQ \& Liang SK. 陈冬华, 蒋德权, 梁上坤. (2012a). 监管者变更与执法力度 (Regulator Change and Enforcement Severity). 中国会计与财务研究 (China Accounting and Finance Review), (2): 111-159.

Chen, F., Peng, S., Xue, S., Yang, Z., \& Ye, F. (2016b). Do audit clients successfully engage in opinion shopping? Partner-level evidence. Journal of Accounting Research, 54(1), 79-112.

Chen, G., Firth, M., Xin, Y., \& Xu, L. (2008). Control transfers, privatization, and corporate performance: Efficiency gains in China's listed companies. Journal of Financial and Quantitative Analysis, 43(1), 161-190.

Chen, GH, \& Lu JQ. 陈国辉, 陆建桥. (1996), 企业产权组织、会计信息质量、会计监督(Enterprise property organization, accounting information quality and accounting regulation). 会计研究(Accounting Research), (5): 33-37.

Chen, G. J., \& Zhang Y. J. 陈国进, 张贻军. (2009). 异质信念、卖空限制与我国股市的暴跌现象研究 (Short Sale Restriction, Heterogeneous Beliefs and Stock Price Crash in China). 金融研究 (Journal of Financial Research), 4, 80-91.

Chen, H., Chen, J. Z., Lobo, G. J., \& Wang, Y. (2010a). Association between borrower and lender state ownership and accounting conservatism. Journal of Accounting Research, 48(5), 973-1014

Chen, H., Chen, J. Z., Lobo, G. J., \& Wang, Y. (2011). Effects of audit quality on earnings management and cost of equity capital: Evidence from China. Contemporary Accounting Research, 28(3), 892-925.

Chen, J. 陈静. (1999). 上市公司财务恶化预测的实证分析(Empirical analysis on the forecasts of financial deterioration in listed firms). 会计研究(Accounting Research), (4): 32-39.

Chen, K. C., Cheng, Q., Lin, Y. C., Lin, Y. C., \& Xiao, X. (2016a). Financial reporting quality of Chinese reverse merger firms: The reverse merger effect or the weak country effect? The Accounting Review, 91(5), 1363-1390.

Chen, L. 陈凌. (1998). 信息特征、交易成本和家族式组织(Information features, transaction costs, and family organization). 经济研究(Economic Research Journal), (7): 28-34

Chen, M. 陈敏. (1995a)，论企业表外筹资(Discussion on off-balance-sheet financing). 会计研究(Accounting Research), (11): 6-10.

Chen, Q., Chen, X., Schipper, K., Xu, Y., \& Xue, J. (2012b). The sensitivity of corporate cash holdings to corporate governance. Review of Financial Studies, 25(12), 3610-3644

Chen, S., Sun, S. Y., \& Wu, D. (2010b). Client importance, institutional improvements, and audit quality in China: An office and individual auditor level analysis. The Accounting Review, 85(1), 127-158.

Chen, SH. 陈少华. (1996), 论我国大学会计硕士研究生教育改革的有关问题(Issues on education about master of accounting). 会计研究(Accounting Research), (7): 35-37.

Chen, SQ. 陈胜群 (1997a)，论日本成本管理的代表模式——成本企画(The representative pattern of cost management in Japan: Cost planning). 会计研究(Accounting Research), (4): 46-47.

Chen, X., Chen X., \& Liu Z.. 陈晓, 陈小悦, 刘钊. (1999). A股盈余报告的有用性研究(A study of the usefulness of A-share firms' earnings reports). 经济研究(Economic Research Journal), 6, 21-28.

Chen, X \& Chen ZH. 陈晓, 陈治鸿. (2000). 中国上市公司的财务困境预测(Predicting Financial Distress in Chinese Listed Firms). 中国会计与财务研究(China Accounting and Finance Review),(3): 55-92.

Chen, XB. 陈学涁. (2005). 中国商业银行薪酬激励机制分析(Analysis on compensation incentive mechanism of Chinese commercial Banks). 金融研究(Journal of Financial Research), (7): 76-94.

Chen, XY. 陈小悦. (1997b), 对会计实证研究方法的认识(Understanding positive accounting research). 会计研 究(Accounting Research), (7): 8-9

Chen, XY, Chen X, \& Gu B. 陈小悦, 陈晓, 顾斌. (1997), 中国股市弱型效率的实证研究(Empirical analysis on the weak efficiency of China's stock market). 会计研究(Accounting Research), (9): 13-17.

Chen, XY, Xia LJ. 陈信元, 夏立军. (2006). 审计任期与审计质量:来自中国证券市场的经验证据(Auditor tenure and Audit Quality: Empirical Evidence from the Chinese Securities Market). 会计研究(Accounting Research),(01): 44-53+93-94.

Chen, XY, Xiao X, Guo XY. 陈小悦, 肖星, 过晓艳. (2000a). 配股权与上市公司利润操纵(Rights and profit control of listed companies). 经济研究(Economic Research Journal), (1): 30-36. 
Chen, Y. C., Hung, M., \& Wang, Y. (2018). The effect of mandatory CSR disclosure on firm profitability and social externalities: Evidence from China. Journal of Accounting and Economics, 65(1), 169-190.

Chen, YG. 陈毓圭. (1995b), 对会计监督的几点看法(Issues on accounting supervision). 会计研究(Accounting Research), (6): 26-28.

Chen, YQ \& Ma LL. 陈玉清, 马丽丽. (2005). 我国上市公司社会责任会计信息市场反应实证分析(Empirical analysis on the reaction of stock markets on CSR information). 会计研究(Accounting Research), (11): 76-81.

Chen YS, \& Xie DR. 陈运森, 谢德仁. (2012). 董事网络、独立董事治理与高管激励 (Board Network, Governance Role of Independent Directors and Executive Incentives). 金融研究 (Journal of Financial Research), (7): 111-119.

Chen, Z., Guan, Y., \& Ke, B. (2013). Are stock option grants to directors of state-controlled Chinese firms listed in Hong Kong genuine compensation? The Accounting Review, 88(5), 1547-1574.

Chow, C. W., Harrison, G. L., McKinnon, J. L., \& Wu, A. (1999). Cultural influences on informal information sharing in Chinese and Anglo-American organizations: An exploratory study. Accounting, Organizations and Society, 24(7), 561-582.

Cull, R., \& Xu, L. C. (2005). Institutions, ownership, and finance: The determinants of profit reinvestment among Chinese firms. Journal of Financial Economics, 77(1), 117-146.

DeFond, M. L., Wong, T. J., \& Li, S. (1999). The impact of improved auditor independence on audit market concentration in China. Journal of Accounting and Economics, 28(3), 269-305.

Deng, CZ. 邓传洲. (2005). 公允价值的价值相关性: B股公司的证据(The Value Relevance of Fair Value:Evidence form B-share Companies). 会计研究(Accounting Research), (10): 55-62+97.

Du, F., Tang, G., \& Young, S. M. (2012). Influence activities and favoritism in subjective performance evaluation: Evidence from Chinese state-owned enterprises. The Accounting Review, 87(5), 1555-1588.

Du, XQ. 杜兴强. (1997), 人力资源会计的确认、计量与报告(The recognition, measurement and disclosure of human resource accounting). 会计研究(Accounting Research), (12): 10-13.

Du, XQ \& Zhou ZJ. 杜兴强, 周泽将. (2010). 政治联系与审计师选择(Political Connection and Auditor Choice). 审计研 究(Auditing Research),(02): 47-53.

Fan, J. P., Wong, T. J., \& Zhang, T. (2007). Politically connected CEOs, corporate governance, and Post-IPO performance of China's newly partially privatized firms. Journal of Financial Economics, 84(2), 330-357.

Fang, J., Pittman, J., Zhang, Y., \& Zhao, Y. (2017a). Auditor choice and its implications for group-affiliated firms. Contemporary Accounting Research, 34(1), 39-82.

Fang, L. H., Lerner, J., \& Wu, C. (2017b). Intellectual property rights protection, ownership, and innovation: Evidence from China. Review of Financial Studies, 30(7), 2446-2477.

Feng, QG. 冯巧根. (1997), 管理会计在我国企业管理中的应用研究(The application of managerial accounting in China). 会 计研究(Accounting Research), (7): 32-34.

Feng, SP, \& Shen XN. 冯淑萍, 沈小南. (1995), 关于环境会计问题的讨论(Discussion on environmental accounting). 会计研 究(Accounting Research), (6): 45-47.

Firth, M., Lin, C., \& Zou, H. (2010). Friend or foe? The role of state and mutual fund ownership in the split share structure reform in China. Journal of Financial and Quantitative Analysis, 45(3), 685-706.

Fu, L. 傅否. (1994)，会计教学的借鉴与思考(Thinking on accounting teaching). 会计研究(Accounting Research), (5): 53-57.

Gao, L, Song SL. 高雷, 宋顺林. (2007). 公司治理与公司透明度(Corporate Governance and Corporate Transparency). 金融研 究(Journal of Financial Research), (11): 28-44.

Ge, JS. 葛家澍. (1997), 基本会计准则与财务会计概念框架(Basic accounting standards and financial accounting conceptual framework). 会计研究(Accounting Research), (10): 1-4.

Ge, JS, \& Chen JS. 葛家澍, 陈箭深. (1995), 略论金融工具创新及其对财务会计的影响(The innovation of financial instruments and its impact on financial accounting). 会计研究(Accounting Research), (8): 1-8.

Ge, JS, \& Li RS. 葛家澍, 李若山. (1992), 九十年代西方会计理论的一个新思潮——绿色会计理论(A new topic of accounting in 1990s: Green accounting theory). 会计研究(Accounting Research), (5): 1-6.

Giannetti, M., Liao, G., \& Yu, X. (2015). The brain gain of corporate boards: Evidence from China. The Journal of Finance, 70(4), 1629-1682.

Gong, Q., Li, O. Z., Lin, Y., \& Wu, L. (2016). On the benefits of audit market consolidation: Evidence from merged audit firms. The Accounting Review, 91(2), 463-488.

Gul, F. A., Wu, D., \& Yang, Z. (2013). Do individual auditors affect audit quality? Evidence from archival data. The Accounting Review, 88(6), 1993-2023.

Guo, F. 郭复初. (1996), 财务理论研究与发展(The research and development of financial management theory). 会计研 究(Accounting Research), (2): 13-16.

Hao, ZP. 郝振平. (1997), 会计研究中案例研究法的应用(The application of case study method in accounting research). 会 计研究(Accounting Research), (7): 17-18.

He, JP. 何建平. (1997), 管理会计在企业中的运用透视(Survey on the application of managerial accounting). 会计研 究(Accounting Research), (6): 39-42.

He, X., Wong, T. J., \& Young, D. (2012). Challenges for implementation of fair value accounting in emerging markets: Evidence from China. Contemporary Accounting Research, 29(2), 538-562.

Hope, O. K., Wu, H., \& Zhao, W. (2018). Blockholder exit threats in the presence of private benefits of control. Review of Accounting Studies, 22(2), 873-902.

Hou, Q., Jin, Q., Yang, R., Yuan, H., \& Zhang, G. (2015). Performance commitments of controlling shareholders and earnings management. Contemporary Accounting Research, 32(3), 1099-1127.

Hu, SM. 胡世明. (1995), 论人力资本保全(The human capital maintenance), 会计研究(Accounting Research), (8): 9-16.

Hu, YM \& Tang SL. 胡奕明, 唐松莲. (2007). 审计、信息透明度与银行贷款利率(Audit, Information Transparency and Bank Loan Interest Rate). 审计研究(Auditing Research),(06): 74-84+73.

Huang, JB, \& Yang XZ. 黄菊波, 杨小舟. (1995), 试论会计政策(Discussion on accounting policy). 会计研究(Accounting Research), (11): 1-5.

Huang, QH. 黄群慧. (2000). 控制权作为企业家的激励约束因素: 理论分析及现实解释意义(Control right as an incentive constraint for entrepreneurs: theoretical analysis and practical significance). 经济研究(Economic Research Journal), (1): 41-47.

Huang, SZ. 黄世忠. (1997a), 公允价值会计:面向21世纪的计量模式(Fair value accounting: measurement mode in 21th century). 会计研究(Accounting Research), (12): 1-4. 
Huang, ZZ. 黄志忠. (1997b), 从会计本质看会计目标与会计职能(Accounting objective and functions from accounting essence). 会计研究(Accounting Research), (6): 33-35.

Hung, M., Wong, T. J., \& Zhang, T. (2012). Political considerations in the decision of Chinese SOEs to list in Hong Kong. Journal of Accounting and Economics, 53(1-2), 435-449.

Jian, M., \& Wong, T. J. (2010). Propping through related party transactions. Review of Accounting Studies, 15(1), 70-105.

Jiang, F., \& Huang J. C. 姜付秀, 黄继承. (2011). 经理激励、负债与公司价值(Managerial Incentive, Debt and Firm Value). 经 济研究(Economic Research Journal), 5, 46-60.

Jiang, G., Lee, C. M., \& Yue, H. (2010). Tunneling through intercorporate loans: The China experience. Journal of Financial Economics, 98(1), 1-20

Jiang, GH，\& Rao PG. 姜国华, 饶品贵. (2011). 货币政策波动、银行信贷与会计稳健性 (Monetary Policy Changes, Bank Credits and Accounting Conservatism). 金融研究(Journal of Financial Research), (5): 15-21.

Jiang, G. H., \& Yue H. 姜国华, 岳衡. (2005). 大股东占用上市公司资金与上市公司股票回报率关系的研究(A Study of the Relationship between Big Shareholders' Diverting Listed Companies' Capital and the Stock Returns of these Companies). 管理世界(Management World), 9, 119-126+157

Jiang, W., Wan, H., \& Zhao, S. (2016). Reputation concerns of independent directors: Evidence from individual director voting. Review of Financial Studies, 29(3), 655-696.

Jiang, XY. 江轩宇. (2013). 税收征管、税收激进与股价崩盘风险(Tax Enforcement, Tax Aggressiveness and Stock Price Crash Risk). 南开管理评论(Nankai Business Review), (5):152-160.

Jin, L., \& Myers, C. S. (2006). R2 around the world: New theory and new tests. Journal of Financial Economics, 79(2), 257-292.

Kachelmeier, S. J., \& Shehata, M. (1997). Internal auditing and voluntary cooperation in firms: A cross-cultural experiment. The Accounting Review, 72(3), 407-431.

Ke, B., Lennox, C. S., \& Xin, Q. (2015). The effect of China's weak institutional environment on the quality of big 4 audits. The Accounting Review, 90(4), 1591-1619.

Lee, C. M., Li, K. K., \& Zhang, R. (2015). Shell games: The long-term performance of Chinese reverse-merger firms. The Accounting Review, 90(4), 1547-1589.

Lee, E., Walker, M., \& Zeng, C. (2014). Do Chinese government subsidies affect firm value? Accounting, Organizations and Society, 39(3), 149-169.

Lei, GY. 雷光勇. (2004). 审计合谋与财务报告舞弊:共生与治理(Audit collusion and financial reporting fraud: symbiosis and governance). 管理世界(Management World), (2): 97-103+116.

Lennox, C., Wu, X., \& Zhang, T. (2016). The effect of audit adjustments on earnings quality: Evidence from China. Journal of Accounting and Economics, 61(2-3), 545-562.

Lennox, C. S., Wu, X., \& Zhang, T. (2014). Does mandatory rotation of audit partners improve audit quality? The Accounting Review, 89(5), 1775-1803.

Li, B, Wu SN. 李博, 吴世农. (2000). 中国股市新股发行 (IPOs) 的初始收益率研究(Study of New Issues' Initial Return in China Stock Market). 南开管理评论(Nankai Business Review), (5): 31-36.

Li, D \& Jia N. 李丹, 贾宁. (2009). 盈余质量、制度环境与分析师预测(Earnings Quality, Institutional Environment and Analyst Forecasts). 中国会计评论(China Accounting Review), (4): 351-370.

Li, DS, \& Zhu L. 李端生, 朱力. (1996), 论现代企业会计政策的选择(The choice of accounting policy for modern enterprises). 会计研究(Accounting Research), (8): 41-43.

Li, K., Wang, T., Cheung, Y. L., \& Jiang, P. (2011). Privatization and risk sharing: Evidence from the split share structure reform in China. Review of Financial Studies, 24(7), 2499-2525.

Li, L., Qi, B., Tian, G., \& Zhang, G. (2017b). The contagion effect of low-quality audits at the level of individual auditors. The Accounting Review, 92(1), 137-163.

$\mathrm{Li}, \mathrm{MH}$, He H \& Ma XK. 李明辉, 何海, 马夕奎. (2003). 我国上市公司内部控制信息披露状况的分析(Analysis on the information disclosure of internal control). 审计研究(Auditing Research), (1): 38-43.

Li, O. Z., Liu, H., Ni, C., \& Ye, K. (2017a). Individual investors' dividend taxes and corporate payout policies. Journal of Financial and Quantitative Analysis, 52(3), 963-990.

Li, S \& Wu X. 李爽, 吴溪. (2004). 监管信号、风险评价与审计定价:来自审计师变更的证据(Regulation signals, risk evaluation and audit fee: Evidence from auditor turnover). 审计研究(Auditing Research),(01): 13-18.

Li, SH. 李树华. (1997)，上市公司境内外审计报告税后净利差异之实证分析(Empirical analysis on the difference of after tax earnings between domestic and overseas audit reports). 会计研究(Accounting Research), (12): 18-23.

Li, S. M., Liu L., \& Yang H. 李守明, 刘玲, 杨桦. (1996), 试析会计决策支持系统(Discussion on decisionsupporting acounting system). 会计研究(Accounting Research), 12, 41-43.

Li, TM. 李天民. (1988), 论管理会计的前景(Prospect of managerial accounting). 会计研究(Accounting Research), (5): 23-28.

Li, YP, Niu JJ. 李远鹏, 牛建军. (2007). 退市监管与应计异象(Delisting Regulation and Accrual Anomaly;). 管理世: 界(Management World), (5): 125-132.

Li, ZJ \& Wang SP. 李志军, 王善平 (2011). 货币政策、信息披露质量与公司债务融资(Monetary Policy, Information Disclosure Quality and Corporate Debt Financing). 会计研究(Accounting Research), (10): 56-62+97.

Li, ZQ. 李增泉. (2000). 激励机制与企业绩效———项基于上市公司的实证研究(Incentives and firm performance: An empirical analysis). 会计研究(Accounting Research), (1): 24-30.

Li, ZQ \& Lu WB. 李增泉, 卢文彬. (2003). 会计盈余的稳健性:发现与启示(Earnings conservatism: Findings and suggestions). 会计研究(Accounting Research), (2): 19-27.

Liao, L., Liu, B., \& Wang, H. (2014). China's secondary privatization: Perspectives from the split-share structure reform. Journal of Financial Economics, 113(3), 500-518.

Lin, CQ. 林长泉. (1997), 不确定性与会计(Uncertainty and accounting), 会计研究(Accounting Research), (11): 21-25.

Lin, S., \& Ye, H. (2018). Foreign direct investment, trade credit, and transmission of global liquidity shocks: Evidence from Chinese manufacturing firms. Review of Financial Studies, 31(1), 206-238.

Liu, B, Ye JZ \& Liao YY. 刘斌, 叶建中, 廖荣毅. (2003). 我国上市公司审计收费影响因素的实证研究——深沪市2001年报的 经验证据(The determinants of audit fee in China). 审计研究(Auditing Research), (1): 44-47.

Liu, F \& Zhou FY. 刘峰, 周福源. (2007). 国际四大意味着高审计质量吗——基于会计稳健性角度的检验(Does the Size Really Matter_—A Perspective of Conservatism Test). 会计研究(Accounting Research), (3): 79-87+94. 
Liu, GS. 刘贵生. (1995), 论产权结构与财务主体(The structure of property right and the entity of financial management). 会 计研究(Accounting Research), (6): 20-21.

Liu, H \& Ye KT. 刘行, 叶康涛. (2013). 企业的避税活动会影响投资效率吗? (Does Corporate Tax Avoidance Affect Investment Efficiency?) 会计研究(Accounting Research), (06): 47-53+96.

Liu, JH. 刘继红. (2009). 国有股权、盈余管理与审计意见(Ownership, Earnings Management and Audit Opinions). 审计研 究(Auditing Research), (2): 32-39.

Liu, LG \& Du Y. 刘立国, 杜荣. (2003). 公司治理与会计信息质量关系的实证研究(An Empirical Research on the Relationship between Corporate Governance and the Quality of Accounting Information). 会计研究(Accounting Research), (2): 28-36+65.

Liu, QL. 刘启亮. (2006). 事务所任期与审计质量一一来自中国证券市场的经验证据(Audit tenure and audit quality: Evidence from China). 审计研究(Auditing Research), (4): 40-49.

Liu, WJ, Mi L \& Fu JX. 刘文军, 米莉, 傅倞轩. (2010). 审计师行业专长与审计质量一一来自财务舞弊公司的经验证 据(Auditor Industry Specialization and Audit Quality: Evidence from financial fraud companies). 审计研究(Auditing Research), (1): 47-54.

Liu，ZW. 刘仲文. (1997)，人力资源价值会计模式探讨(Discussion on the valuation of human resource). 会计研 究(Accounting Research), (6): 16-20.

Lu, DM. 陆德民. (1996), 衍生金融工具的发展及其所带来的会计问题(The development of financial derivatives and the accounting issues). 会计研究(Accounting Research), (7): 1-5.

Lu, JQ. 陆建桥. (1999). 中国亏损上市公司盈余管理实证研究(Earnings management in loss firms). 会计研究(Accounting Research),(09): 25-35.

Lu, ZF. 陆正飞. (1995)，论现代企业成本的战略管理(Strategy management of costs in modern enterprises). 会计研 究(Accounting Research), (7): 29-32.

Lu, ZF \& Xin Y. 陆正飞, 辛宇. (1998). 上市公司资本结构主要影响因素之实证研究(The determinants of corporate leverage). 会计研究(Accounting Research), (8): 36-39.

Luo, F. 罗飞. (1997), 谈论商誉的性质及购买商誉的会计处理(Discussion of the essence of goodwill and its accounting processes). 会计研究(Accounting Research), (1): 45-47.

Luo, JH \& Du XQ. 罗进辉, 杜兴强. (2014). 媒体报道、制度环境与股价崩盘风险(Media Coverage, Institutional Environment and Stock Price Crash Risk). 会计研究(Accounting Research), (9): 53-59+97.

Lyu, CJ, Yan MZ, Zheng HL \& Xu JJ. 吕长江, 严明珠, 郑慧莲, 许静静. (2011). 为什么上市公司选择股权激励计划? (Why Corporates Choose Stock Option? Evidence from China). 会计研究(Accounting Research), (1): 68-75+96.

Mao, FG. 毛付根. (1995), 论营运资金管理的基本原理(The fundamental principles of working capital management), 会计研 究(Accounting Research), (1): 38-40.

Mao, XS \& Dai DM. 毛新述, 戴德明. (2009). 会计制度改革、盈余稳健性与盈余管理(A Study on Earnings Conservatism and Earnings Management based on the Change of China Accounting System). 会计研究(Accounting Research), (12): 38-46+96.

Meng, FL. 孟凡利. (1997a), 环境会计:叹待开发的现代会计新领域(Environmental accounting: A new accounting area). 会计 研究(Accounting Research), (1): 18-21.

Meng, FL. 孟凡利. (1997b), 环境会计的概念与本质(The concept and essence of environmental accounting). 会计研 究(Accounting Research), (12): 45-46.

Meng, Y. 孟焰. (1997c), 论管理会计的规范化(The normalization of managerial accounting). 会计研究(Accounting Research), (3): 35-39.

O'Connor, N. G., Deng, J., \& Luo, Y. (2006). Political constraints, organization design and performance measurement in China's state-owned enterprises. Accounting, Organizations and Society, 31(2), 157-177.

Piotroski, J. D., \& Zhang, T. (2014). Politicians and the IPO decision: The impact of impending political promotions on IPO activity in China. Journal of Financial Economics, 111(1), 111-136.

Qiao, YJ. 乔彦军. (1997), 为什么国有企业在应用管理会计上乏力?(Why there is weak application of managerial accounting in state-owned firms?). 会计研究(Accounting Research), (4): 33-36.

Quan, X. F., Wen F., \& Wu S. N. 权小锋, 文芳, 吴世农. (2010). 管理层权力、私有收益与薪酬操纵 (Managerial Power, Private Income and Compensation Rigging). 经济研究(Economic Research Journal), 2, 64-68+83.

Quan, XF，\& Wu SN. 权小锋，吴世农. (2010). 投资者关注、盈余公告效应与管理层公告择机 (Investor Attention, Earnings Announcement Effect and Announcement Timing of Management). 金融研究(Journal of Financial Research), (9): 129-136.

Shi, S., Sun, Q.. \& Zhang, X. (2018). Do IPOs affect market Price? Evidence from China. Journal of Financial and Quantitative Analysis, 53(3), 1391-1416.

Song, XZ. 宋献中. (1995), 中国管理会计(Managerial accounting in China). 会计研究(Accounting Research), (11): 14-17.

Sun, H. 孙航. (1995), 作业成本计算的应用研究(The application of activity-based cost management), 会计研究(Accounting Research), (9): 21-24.

Sun, Z. 孙铮. (1997), 有效市场与会计信息关系研究(The relation between efficient market and accounting information). 会 计研究(Accounting Research), (3): 2-12.

Sun, Z \& Cao Y. 孙铮，曹宇. (2004). 股权结构与审计需求(Ownership structure and audit demand). 审计研究(Auditing Research), (3): 7-14.

Tang, GL. 汤谷良. (1994)，现代企业财务的产权思考(Thinking about property right for modern enterprise financial management), 会计研究(Accounting Research), (5): 6-10.

Tang, QQ \& Xu X. 唐清泉, 徐欣. (2010). 企业R\&D投资与内部资金一一来自中国上市公司的研究(R\&D Investment and Internal Finance: the Research on Chinese Listed Companies). 中国会计评论(China Accounting Review), (03): 341-362.

Tang, S., Zhou G. L., Yu X. H., \& Sun Z. 唐松, 周国良, 于旭辉, 孙铮. (2008). 股权结构、资产质量与关联担保一一来自中国 A股上市公司的经验证据(Ownership Structure, Asset Quality, and Related-party Loan Guarantees Evidence from Chinese A-Share Listed Companies). 中国会计与财务研究(China Accounting and Finance Review), 2, 62-113.

Tang, T., Mo, P. L. L., \& Chan, K. H. (2017). Tax collector or tax avoider? An investigation of intergovernmental agency conflicts. The Accounting Review, 92(2), 247-270.

Tang, V. W. (2011). Isolating the effect of disclosure on information risk. Journal of Accounting and Economics, 52(1), 81-99.

Tang, XS, Zhou XS \& Ma RJ. 唐雪松, 周晓苏, 马如静 (2007). 上市公司过度投资行为及其制约机制的实证研究(Empirical Research on Over-investment Behavior and its Restriction Systems in China's Listed Companies). 会计研究(Accounting Research), (7): 44-52+96. 
Tang, YW, \& Lu JQ. 汤云为, 陆建桥. (1997), 财务会计发展所面临的挑战与出路(Challenge and outlet for financial accounting in China). 会计研究(Accounting Research), (1): 9-17.

Tian, ZL, \& Li YQ. 田志龙, 李玉清. (1997), 一种基于账面价值和未来收益的公司财富评估方法(Valuation methods based on book value and future profit). 会计研究(Accounting Research), (5): 47-49.

Wang, B. 王斌. (1997a), 现金流转说:财务经理的财务观点(Financial management based on cash flow: A view from CFO). 会 计研究(Accounting Research), (5): 30-34.

Wang, HC \& Tong Y. 王化成, 佟岩. (2006). 控股股东与盈余质量一一基于盈余反应系数的考察(Controlling shareholders and earnings quality: An empirical study based on earnings response coefficients). 会计研究(Accounting Research), (2): 66-74+97.

Wang, HC, \& Yang JY. 王化成, 杨景岩. (1997), 试论战略管理会计(Managerial accounting based on corporate strategy). 会 计研究(Accounting Research), (10): 46-49.

Wang, PC. 王鹏程. (1997b), 对盈利预测若干问题的分析和研究(Research on earnings forecasts issues). 会计研 究(Accounting Research), (3): 13-28.

Wang, Q., Wong, T. J., \& Xia, L. (2008). State ownership, the institutional environment, and auditor choice: Evidence from China. Journal of Accounting and Economics, 46(1), 112-134.

Wang, YT \& Chen SM. 王跃堂, 陈世敏. (2001). 脱钩改制对审计独立性影响的实证研究(The impact of Auditing Organization Reform on audit independence). 审计研究(Auditing Research), (3): 2-9.

Wang, YT, \& Wang YC. 王玉涛, 王彦超. (2012). 业绩预告信息对分析师预测行为有影响吗 (Does Earnings Preannouncement Information Impose Effects on the Forecast Behavior of Financial Analysts?). 金融研究(Journal of Financial Research), (8): 77-84+139.

Wu, J. 吴俊. (1994), 关于社会责任会计的几点思考(Some thinking on social responsibility accounting). 会计研 究(Accounting Research), (6): 12-14.

Wu, LN. 伍利娜. (2003). 审计定价影响因素研究——来自中国上市公司首次审计费用披露的证据(The Determinants of Audit Fee: Evidence from Chinese Stock Market's First-time Disclosure of Audit Fee). 中国会计评论(China Accounting Review),(00): 113-128.

Wu, LS \& Liu HL. 吴联生, 刘慧龙. (2008). 中国审计实证研究:1999-2007(Empirical Research of Auditing in China:1999-2007). 审计研究(Auditing Research),(02): 36-46.

Wu, Q. 吴群. (1997), 衍生金融工具及其会计思考(Financial derivatives and its thinking). 会计研究(Accounting Research), (10): 18-21.

Wu, WF, Wu CF, \& Rui M. 吴文锋, 吴冲锋, 获萌. (2009). 中国上市公司高管的政府背景与税收优惠(Political background of managers and tax benefits). 管理世界(Management World), (3):134-142.

Wu, YH \& Wu SN. 吴育辉, 吴世农. (2010). 高管薪酬激励还是自利? 一一来自中国上市公司的证据(Executive Compensation: Incentives or Self-Interests? Evidence from Listed Firms in China). 会计研究(Accounting Research), (11): 40-48+96-97.

Wu, ZX. 伍中信. (1996), 受托责任论一一会计本事理论的重新确认(Stewardship: Reconfirmation on accounting essence theory). 会计研究(Accounting Research), (11): 35-35.

Xia, DL, \& Liu F. 夏冬林, 刘峰. (1995), 试论会计管制与政府行为(Accounting regulation and government activities). 会计研 究(Accounting Research), (5): 16-22.

Xia, LJ. 夏立军. (2003). 盈余管理计量模型在中国股票市场的应用研究(Application of Earnings Management Measuring Models in the Chinese Stock Market ). 中国会计与财务研究(China Accounting and Finance Review), (2): 94-154.

Xiang, DW. 向德伟. (1994), 论财务风险(Discussion of financial risk). 会计研究(Accounting Research), (4): 21-25.

Xiao, ZZ，\& Pan AX. 肖泽忠，潘爱香. (1996)，运用ABC改善企业管理(Using activity-based cost manage to improve management efficiency). 会计研究(Accounting Research), (5): 13-15.

Xie, DR. 谢德仁. (1995), 会计理论研究的逻辑起点及会计理论体系(The logical starting point and accounting theory framework in accounting theory research). 会计研究(Accounting Research), (4): 1-6.

Xie, ZH. 谢志华. (1997), 出资者财务论(Financial management based on the perspective of investors), 会计研究(Accounting Research), (5): 24-29.

Xin, QQ, Lin B. Wang YC. 辛清泉, 林斌, 王彦超. (2007). 政府控制、经理薪酬与资本投资(Government Control, Executive Compensation and Capital Investment). 经济研究(Economic Research Journal), (8): 110-122.

Xu，NH，Yi ZH，\& Yu SY. 许年行，伊志宏，于上尧. (2013). 机构投资者羊群行为与股价崩盘风险 (Institutional Investor Herding and Stock Price Crash Risk). 管理世界(Management World), (9): 76-84+128.

Xu, Y., \& Xu, X. (2016). Taxation and state-building: The tax reform under the nationalist government in China, 1928-1949. Accounting, Organizations and Society, 48, 17-30.

Xue, YK. 薛云奎. (1997), 手工会计的技术特征及其对电算化会计的局限(The characteristics of manual accounting and its limitation to computerized accounting system). 会计研究(Accounting Research), (11): 7-12.

Yan, DW, \& Geng JX. 阎达五, 耿建新. (1996), 论国有企业过度负债的成因与对策(The determinants and solutions for debt overhang of state-owned companies). 会计研究(Accounting Research), (8): 11-15.

Yan, DW, \& Xu JC. 阎达五, 徐经长. (1995), 金融工具会计——国际会计准则第48号征求意见稿简介(Accounting for financial instruments: An introduction of the exposure draft of IAS 48). 会计研究(Accounting Research), (8): 41-44.

Yang, DM, \& Zhao C. 杨德明, 赵秝. (2012). 媒体监督、媒体治理与高管薪酬 (Media Monitoring, Media Governance and Managers' Compensation). 经济研究(Economic Research Journal), (4): 73-79+85.

Yang, JW, \& Yan DW. 杨纪琬, 阎达五. (1980), 开展我国会计理论研究的几点意见(Several suggestions for accounting theory research in China). 会计研究(Accounting Research), (1): 2-10.

Yang, YH \& Wang W. 杨有红, 汪薇. (2008). 2006年沪市公司内部控制信息披露研究(Research on Internal Control Information Disclosure of Public Listed Companies in Shanghai Stock Exchange in 2006). 会计研究(Accounting Research), (3): 35-42+95.

Yang, Z. (2013). Do political connections add value to audit firms? Evidence from IPO audits in China. Contemporary Accounting Research, 30(3), 891-921.

Yang ZL \& Xu ZD. 杨忠莲, 徐政旦. (2004). 我国公司成立审计委员会动机的实证研究(The incentives of audit committee establishment). 审计研究(Auditing Research),(01): 19-24.

Yang, ZS, \& Yao SY. 杨之曙, 姚松瑶. (2004). 沪市买卖价差和信息性交易实证研究(Bid-Ask Spread and Informed Trading: Evidence from Shanghai Stock Exchange). 金融研究(Journal of Financial Research), (4): 45-56. 
Ye KT, Cao, F, Wang HC, \& 叶康涛, 曹丰, 王化成. (2015). 内部控制信息披露能够降低股价崩盘风险吗? (Can Internal Control Information Disclosure Reduce Stock Price Crash Risk?). 金融研究 (Journal of Financial Research), (6): 62-68+92.

Yu, ZB. 于增彪. (1996), 略论我国会计职业道德(Discussion on accounting ethics in China). 会计研究(Accounting Research), (10): 9-14.

Yuan, HQ \& Li HJ. 原红旗, 李海建. (2003). 会计师事务所组织形式、规模与审计质量(The organization form of audit firms, audit firm size, and audit quality). 审计研究(Auditing Research), (1): 32-37.

Yue, H \& Lin XC. 岳衡, 林小驰. (2008). 证券分析师VS统计模型:证券分析师盈余预测的相对准确性及其决定因素(Financia Analyst vs. Statistical Model: The Relative Accuracy of Analyst Forecasts and Its Determinants). 会计研究(Accounting Research), (8): 40-49+95.

Zeng, Y \& Ye KT. 曾颖, 叶康涛. (2005). 股权结构、代理成本与外部审计需求(Ownership Structure, Agency Cost and External Auditing Demand). 会计研究(Accounting Research),(10): 63-70+97.

Zhang, DL \& Li SH. 张敦力，李四海. (2012). 社会信任、政治关系与民营企业银行贷款(Social Trust, Political Relationship and the Private Enterprises' Bank Loans). 会计研究(Accounting Research), (8): 17-24+96.

Zhang, JR. 张俊瑞. (1987), 关于人力资源会计的几个问题(Issues on human resource accounting). 会计研究(Accounting Research), (2): 45-47.

Zhang, R, Ye KT, Lu ZF. 张然, 陆正飞, 叶康涛. (2007). 会计准则变迁与长期资产减值(Accounting Standards Change and Long-Term Asset Impairment). 管理世界(Management World), (8): 77-84+139.

Zhang, WG, \& Xu ZY. 张为国，徐宗宇. (1997), 实证研究、会计选择、证券市场(Empirical research, accounting choice and stock market). 会计研究(Accounting Research), (10): 5-13.

Zhang, WX. 张文贤. (1995)，人力资源会计的四大难题(Four puzzles for human resource accounting). 会计研究(Accounting Research), (12): 20-22.

Zhang, XZ. 张先治. (1997), 中国企业财务管理目标探讨(Study on the objective of Financial Management in China). 会计研 究(Accounting Research), (11): 13-17.

Zhang, ZT. 张正堂. (2008). 企业内部薪酬差距对组织未来绩效影响的实证研究(The impact of pay gap on future performance). 会计研究(Accounting Research), (9): 81-87.

Zhao, BQ. 赵保卿. (1995a), 论人力资源会计的几个问题(Some issues about human resource accounting). 会计研 究(Accounting Research), (12): 23-26.

Zhao, DW. 赵德武. (1995b), 论西方会计目标理论不同学派的会计思想(Different accounting philosophy on accounting objective). 会计研究(Accounting Research), (4): 7-11.

Zhao, YL, Wang ZT. 赵宇龙, 王志台. (1999). 我国证券市场“功能锁定 现象的实证研究(An empirical study on the phenomenon of "functional locking" in China's securities market). 经济研究(Economic Research Journal), (9): 56-63.

Zhou, QW , Zhong XF, \& Wu AN. 周齐武, 钟西飞, 吴安妮. (1997), 中国会计教育与研究之现状(Current situation of Accounting Education in China). 会计研究(Accounting Research), (11): 34-40.

Zhou, SH, Yang JH, \& Wang P. 周首华，杨济华，王平. (1996)，论财务危机的预警分析——F分数模式 (The warning analysis of financial distress: A F-score mode). 会计研究(Accounting Research), (8): 8-11.

Zhou, Z. H. (1988). Chinese accounting systems and practices. Accounting, Organizations, and Society, 13(2), 207-224.

Zhu, CF \& Li ZW. 朱茶芬, 李志文. (2008). 国家控股对会计稳健性的影响研究(State Ownership and Accounting Conservatism). 会计研究(Accounting Research), (5): 38-45+95.

Zhu, HJ, Xia LJ \& Chen XY. 朱红军, 夏立军, 陈信元. (2004). 转型经济中审计市场的需求特征研究(Audit demand in transition economy). 审计研究(Auditing Research), (5): 53-62.

\section{Submit your manuscript to a SpringerOpen ${ }^{\circ}$ journal and benefit from:}

- Convenient online submission

- Rigorous peer review

- Open access: articles freely available online

- High visibility within the field

- Retaining the copyright to your article

Submit your next manuscript at $\boldsymbol{\nabla}$ springeropen.com 